\title{
AUTONOMOUS GEOGRAPHIES IN AOTEAROA: CAMP FOR CLIMATE ACTION AND THE POLITICS OF CLIMATE CHANGE
}

\author{
by \\ Elizabeth Willoughby-Martin \\ Thesis \\ ENVIRONMENTAL STUDIES 593
}

A 90 point thesis submitted to Victoria University of Wellington, as partial fulfillment of requirements for the degree of Master of Environmental Studies

School of Geography, Environment and Earth Sciences

Victoria University of Wellington

[2012] 





\title{
AUTONOMOUS GEOGRAPHIES IN AOTEAROA: CAMP FOR CLIMATE ACTION AND THE POLITICS OF CLIMATE CHANGE
}

\author{
Elizabeth Willoughby-Martin
}

\begin{abstract}
In the last two decades a new form of social movement has spread internationally, characterized by political autonomy, direct action, radical change, and decentralized organization. In response to academic misunderstandings of these new movements, critical geographers have coined the term 'autonomous geographies' to allow effective documentation and communication of these struggles. This research uses autonomous geographies and related discourses to explore how autonomous political collective Camp for Climate Action Aotearoa contributes to the politics of climate change in New Zealand. As an active participant in Camp for Climate Action Aotearoa I have utilized a scholar activist epistemological framework throughout the research process, allowing successful navigation of these interconnected identities. Critical discussion of qualitative data gathered in semi-structured interviews with long-term participants indicates that Camp for Climate Action Aotearoa provides significant support to activists through community and affective solidarity. Camp for Climate Action Aotearoa uses direct action and direct democracy processes which contribute to everyday activist practices and express a nonhegemonic 'logic of affinity'. Data analysis indicates Camp for Climate Action Aotearoa contributes to the creation of alternative futures in the present. These alternative futures are necessary for healthy democracies. Physical climate camps are particularly significant in providing opportunities for creating these alternative visions. Climate Camp Aotearoa is a genuinely political collective that contributes to a repoliticization of climate change in New Zealand.
\end{abstract}

Key words: activism; affective solidarity; autonomous geographies; climate change; logic of affinity; New Zealand 


\section{Acknowledgements}

The gestation of this thesis has been an important journey for me both academically and as a politically active person. During this time I have received considerable support from many sources. I would like to offer gratitude to the following people:

To my supervisor, Dr Jessica Hutchings: for sharing her knowledge and giving me deadlines.

Thanks to Dr Sophie Bond for her early assurances that anti-capitalist academia does exist, and for making useful suggestions at integral moments.

I am greatly indebted to my office-mates Jodie Robertson, Alana Cornforth and Alejandra Perez for seemingly endless solidarity, sympathy and (sometimes) wine.

Cheers to the lovely Jessie Prebble for hugs, advice and tea. A big thank you to Jessie Dennis for being integral to my experience of climate justice activism. Extreme appreciation goes out to Joe McCarter for being swell, notably in making my life bearable post tibial fractures. Thanks must also be directed towards Ants Cabraal, for his boundless enthusiasm, toasted sandwiches and general shaman-like qualities.

As always, I am grateful to my Mum, Sue Willoughby, for all her support. I offer a nod to my Dad, Paul Martin, who has been a significant influence in the creation of my own personal epistemological framework.

My deepest gratitude goes to everyone involved in Camp for Climate Action Aotearoa, especially those people who participated in this research. Your insights have been invaluable; I can only hope this thesis will prove useful in whatever is to come. Respect and affection goes out to all those involved in the Climate Camp Wellington local group which has provided me with such a cosy political community. Thank you. 


\section{Table of Contents}

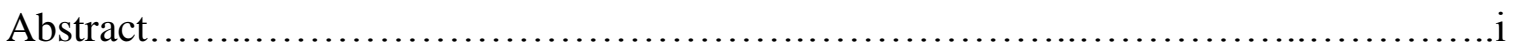

Acknowledgments.............................................................

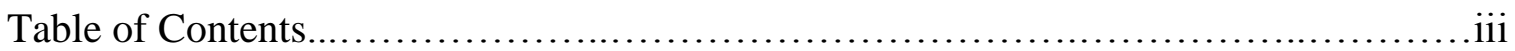

Figures................................................................. vi

Chapter One: Introduction..................................................

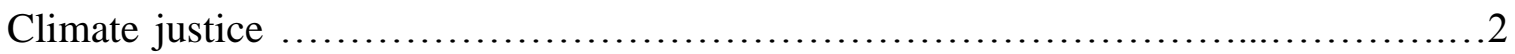

Climate Camp Aotearoa.....................................................4

Scholar activism...............................................................

Autonomous geographies.........................................................

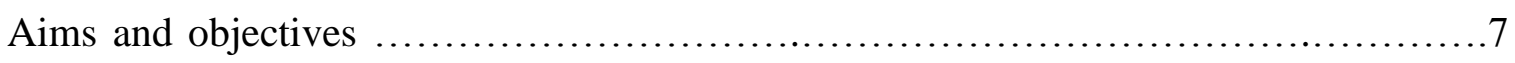

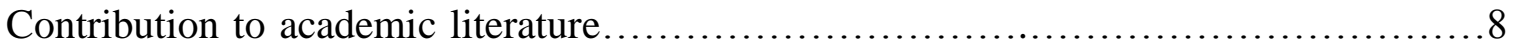

Thesis structure and outline......................................................

Chapter Two: Contextualizing Climate Camp Aotearoa...........................11

Early resistance to colonisation.............................................. 11

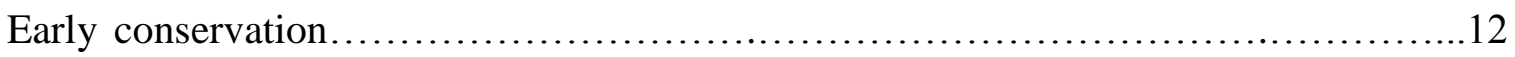

The early labour movement...............................................

Decades of protest......................................................... 13

Resistance to neoliberalism............................................... 17

Activism in the early $21^{\text {st }}$ Century ........................................... 17

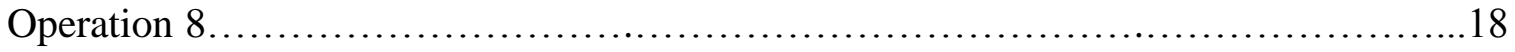

Current context of activism................................................... 19

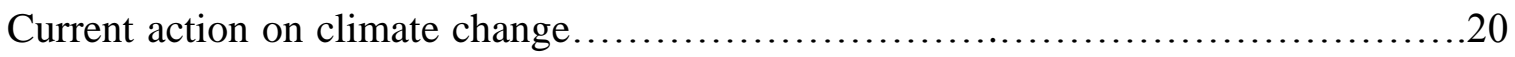

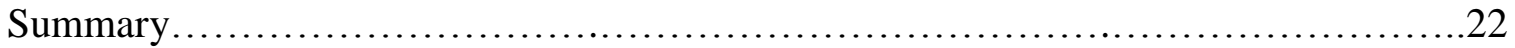

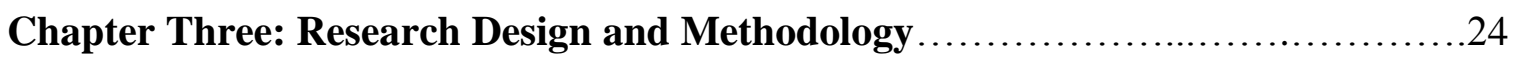

Feminist geographies.................................................... 24

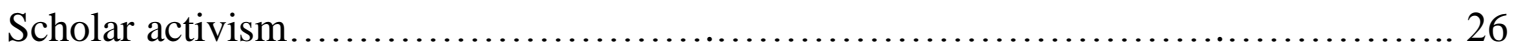




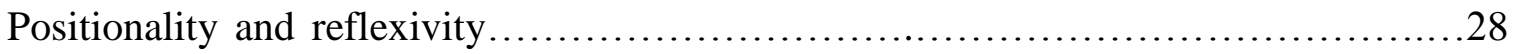

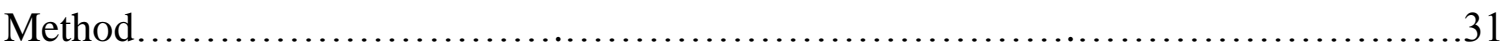

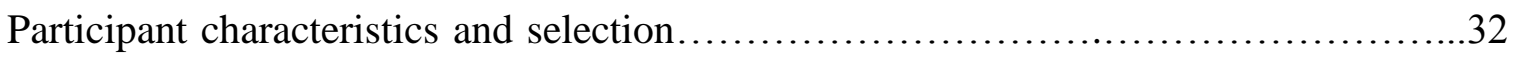

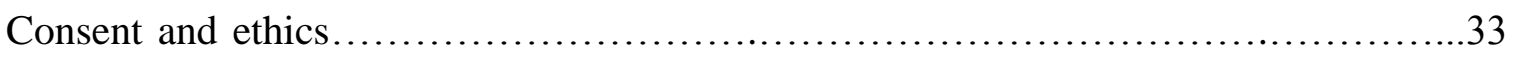

Research journal...............................................................

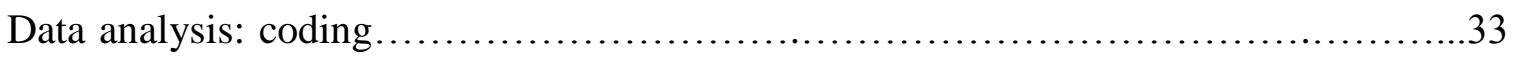

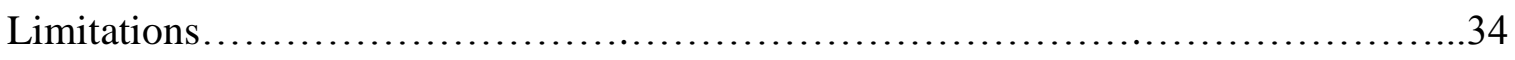

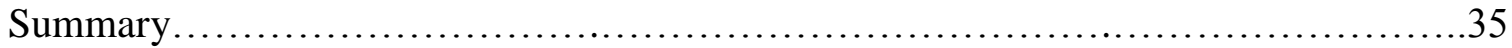

Chapter Four: Literature Review........................................ 36

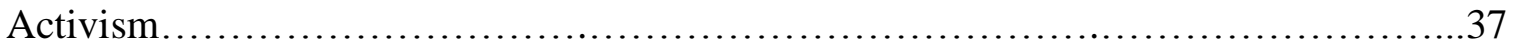

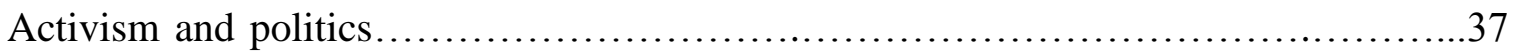

Autonomous geographies............................................... 39

Alternative futures...........................................................40

Everyday activism........................................................... 41

Global Justice Networks................................................42

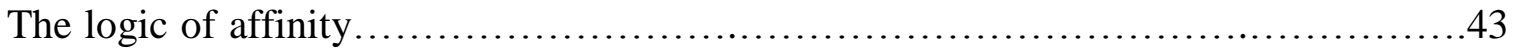

Direct democracy processes..............................................44

Direct action............................................................. 46

Activist politicization....................................................47

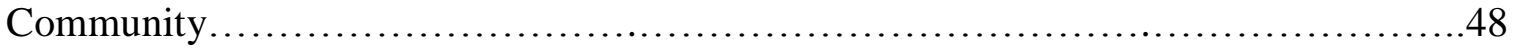

Emotions..............................................................49

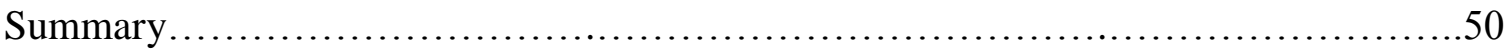

Chapter Five: Data Presentation.......................................... 53

Key interview themes.....................................................

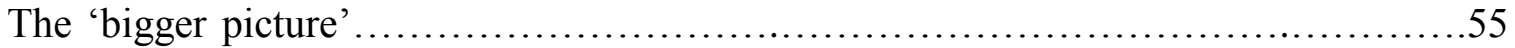

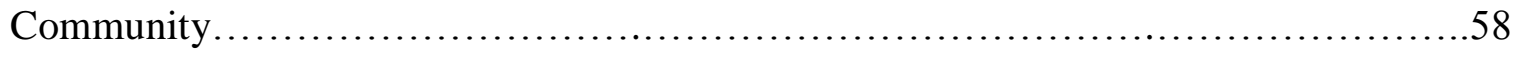

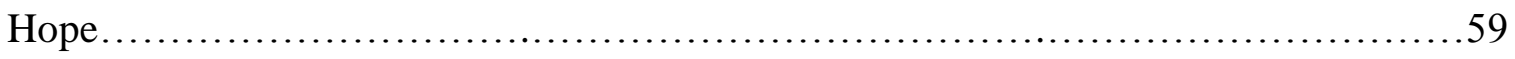

Direct democracy processes..............................................61

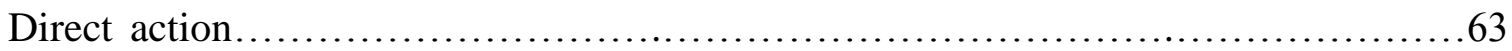


Politicization...............................................................65

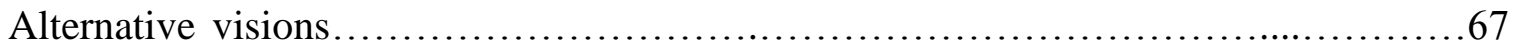

Chapter Six: Critical Discussion......................................... 70

Research Objective One....................................................... 70

Research Objective One: Summary........................................ 75

Research Objective Two.................................................. 75

Research Objective Two: Summary.............................................79

Research Objective Three................................................ 80

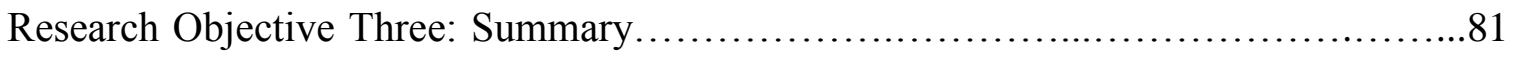

Chapter Seven: Critical Discussion........................................... 83

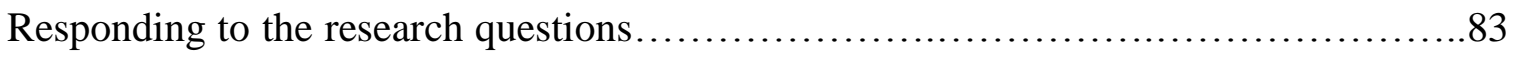

Utilising a scholar activist epistemological framework ............................84

Contribution to Climate Camp Aotearoa............................................85

Future research........................................................... 87

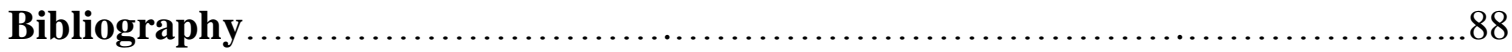

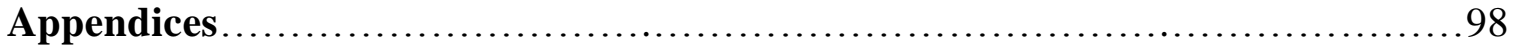

Appendix One - Interview Guide..........................................98

Appendix Two - Consent Form............................................ 99

Appendix Three - Information Sheet.................................... 100 


\section{Figures}

Figure 1: Scholar activist epistemological framework..........................27 


\section{Chapter One}

\section{Introduction}

True utopia is when the situation is so without issue, without a way to resolve it within the coordinates of the possible that out of the pure urge of survival you have to invent a new space. Utopia is not kind of a free imagination; utopia is a matter of innermost urgency. You are forced to imagine it as the only way out, and this is what we need today (Zizek, in Taylor, 2007).

\section{Introduction}

Climate change ${ }^{1}$ is widely considered to be the most pressing issue facing humankind (Stern, 2007). However, academics from a variety of fields have acknowledged the linkages between a wide range of accelerating global crises, including climate change, the global financial crisis, widespread species extinctions and the overconsumption of natural resources. Increasingly, a view is expressed that these crises are symptoms of a larger problem: the unjust and unsustainable growth stemming from our current societal and economic systems (eg: Crutzen and Stoermer, 2000). Criticism has been particularly directed towards corporate globalisation, neoliberalism and capitalism (eg: GibsonGraham, 1996; Swyngedouw, 2008).

Academic discourses pertaining to these crises have been in part influenced by the global social movements and activism of recent decades. In the 90's the so-called 'global justice movement' emerged, inspired by autonomous political movements such as the Mexican Zapatistas (Pickerill and Chatterton, 2006). The global justice movement is made up of many movements and differs significantly from past social movements in displaying characteristics such as direct action, radical change, autonomy, decentralized organization and the rejection of hierarchy (ibid). Gibson-Graham (2006) describes a key difference

\footnotetext{
${ }^{1}$ Climate change describes "a change of climate which is attributed directly or indirectly to human activity that alters the composition of the global atmosphere and which is in addition to natural climate variability observed over comparable time periods" (UNFCCC, 1994:1).
} 
between these new movements and traditional leftist politics:

Our movements are trying to create a politics that challenges all the certainties of traditional leftist politics, not by replacing them with new ones, but by dissolving any notion that we have answers, plans or strategies that are watertight or universal [...] When we are asked how we are going to build a new world, our answer is "We don't know, but let's build it together." (Gibson-Graham, 2006: xix)

These movements open up new terrain and encourage the concept of 'revolution' to be rethought as 'changing the world without taking power' (Holloway, 2002; Vaneigem, 1979). Many of the groups and networks that made up the global justice movement have evolved naturally into a global 'climate justice' movement (Notes From Below, 2010).

\section{Climate justice}

The Global Justice Ecology Project (n.d) describes climate justice as the following:

The heart of climate justice is the understanding that the urgent action needed to prevent climate change must be based on community-led solutions and the wellbeing of local communities, Indigenous Peoples and the global poor, as well as biodiversity and intact ecosystems.

Climate justice is the understanding that we will not be able to stop climate change if we don't change the neo-liberal, corporate-based economy that stops us from achieving sustainable societies. It is the understanding that corporate globalization must be stopped (ibid:1).

The Building Bridges Collective (2010) state that the term 'climate justice' became popular during the $14^{\text {th }}$ Conference of Parties (COP) held in Bali in 2007. In 2009, before the $15^{\text {th }} \mathrm{COP}$ in Copenhagen, climate justice became a mobilizing connection between groups opposing what was considered:

$[\ldots]$ an unjust set of negotiations interested in expanding capitalism rather than in 
addressing the global climate crises (Building Bridges Collective, 2010: 27).

A climate justice worldview rejects market-based and business-focused climate mitigation measures such as those endorsed by the United Nations Framework Convention on Climate Change (UNFCCC) on grounds that they perpetuate the root causes of climate change and biodiversity loss (Global Justice Ecology, n.d.). Instead, the real solutions to climate change are seen as originating from peoples and communities who live in sustainable ways (ibid).

Furthermore, a climate justice worldview recognizes that historically industrialized countries have responsibility for the majority of greenhouse gas emissions (Building Bridges Collective, 2010), and demands that both industrial and preindustrial nations immediately transition to low carbon economies, the latter with assistance and resources from industrialised nations (Global Justice Ecology, n.d.). They recognize that those significantly affected by climate change are:

Indigenous Peoples, peasant communities, fisherfolk, and especially women in these communities (ibid: 1).

A climate justice perspective acknowledges that these people are also those most affected by the implementation of 'false solutions' purported to tackle climate change, such as carbon trading (Muller and Passadakis, 2009; Brunnengraeber, 2009).

For many people involved in climate justice movements the politicization of climate change is highly significant: a shift away from understanding climate change as an environmental issue to understanding climate change as a result of current and historical societies (Building Bridges Collective, 2010). Climate justice struggles may not be targeted directly at the issue of climate change but can encompass resistance to exploitation, trade agreements and privatization of resources (ibid).

Overall, climate justice is a fluid and diverse umbrella: groups and individuals may utilize direct action tactics or may not; some may state an opposition to capitalism, others may state an opposition to neoliberalism (see Building Bridges Collective, 2010). This 
loose definition encompasses many collectives, groups and organizations working internationally for indigenous rights, workers rights, women's rights and environmental justice. In Aotearoa ${ }^{2}$, Camp for Climate Action Aotearoa (henceforth shortened to Climate Camp Aotearoa) is a collective that utilizes climate justice principles.

\section{Climate Camp Aotearoa}

Inspired by 'Climate Camps' being held in the United Kingdom Climate Camp Aotearoa was formed at the end of 2008. Climate Camps began in 2006 in the UK with the aim of catalyzing a climate movement (Camp for Climate Action, n.d) A primary objective of Climate Camp Aotearoa was to build a social movement to tackle the root causes of climate change (Camp for Climate Action Aotearoa, n.d).

Climate Camp Aotearoa has consisted of ongoing 'local groups' based in various geographic centers around Aotearoa, and one physical Climate Camp. This physical Climate Camp occurred in November 2009 in Lower Hutt, near Wellington (Camp for Climate Action Aotearoa, n.d.).

Activists are able to challenge oppressive power ${ }^{3}$ structures through the practice of resistance: the opposition to oppressive power dynamics (Routledge, 2010). For the purpose of this research the above description is used to define an activist, and thus Climate Camp Aotearoa research participants are considered activists due to collective resistance. Viewing participants as activists allows this research to be positioned within geographical discourses concerned with activism.

From the beginning of April 2009 I have been an active participant in Climate Camp Aotearoa. This prior involvement was a core reason behind my initial decision to focus on Climate Camp Aotearoa. As an embedded participant in this research I have chosen to utilize the epistemological lens of a scholar activist.

\footnotetext{
${ }^{2}$ Aotearoa New Zealand will be referred to as Aotearoa for the duration of this thesis.

${ }^{3}$ Power is defined as the "ability of one agent to affect the actions or attitudes of another" (Gregory et al. 2010: 575).
} 


\section{Scholar activism}

Chatterton, Hodkinson and Pickerill (20010) suggest that it is relatively rare for geographers to deliberately combine their academic work with their politics, and that even fewer geographers are actively involved in social movements. As Kitchin and Hubbard (1999) state:

CVs of contemporary human geographers might reveal a discipline riddled with hunt saboteurs, anti-road protestors, green activists, charity workers and homeless advocates (not to mention local councilors, community representatives and magistrates). But it appears the most seek to maintain a scholarly 'distance' between their activism and their teaching, research and publishing activities, and do not incorporate such activist concerns into their 'disciplinary' life (ibid: 193).

Responding to this gap within the sub-discipline of critical geography, 'scholar activists' - those who act as both academics and activists - have attempted document and explore their own engagements within this dual world (eg: Maxey 1999; Routledge 2003; Pain and Francis, 2003).

Chatterton, Hodkinson and Pickerill (2010) maintain that scholar activists align their research with the following principles: to challenge neoliberal universities; to recognize and use their strengths as academics; to contribute to a global 'knowledge commons'; to be aware of their own impacts in research; to create scholar activist networks; to use socially and ecologically responsible methods; and to strategically intervene in social movements.

In choosing to consider myself as a scholar activist, I have attempted to implement as many of these principles as a thesis framework allows (see Chapter Three). The use of this epistemological lens has informed the methods and engagement with academia I have selected for the purpose of this research. Autonomous geography discourses have been the basis of my engagement with academia. 


\section{Autonomous geographies}

Autonomous geographies are defined as:

$[\ldots]$ those spaces where there is a questioning of the laws and social norms of society and a creative desire to constitute non-capitalist, collective forms of politics, identity and citizenship (Pickerill and Chatterton, 2006:730).

'Autonomous geographies' is a term coined by scholar activists Pickerill and Chatterton in response to academic misunderstandings of the global justice movement. These understandings were largely due to unfamiliar methods of organizing, as Pickerill and Chatterton (ibid) explain:

Commentators make the mistake of looking for signs of emerging organizational coherence, political leaders and a common programme that bids for state power, when the rule of engagement have changed (ibid: 739).

The rules of engagement have changed because the global justice movement and the global climate justice movement use decentralized organizational processes, functioning as networks. Groups making up the climate justice movement are autonomous ${ }^{4}$; working together as a network, rather than a vertically organized entity. Thus, Pickerill and Chatterton argue that these new movements need new tools to effectively examine them.

Documenting and communicating the socio-spatialities of autonomous struggles can inspire other collectives and groups to create their own forms of collective post-capitalist practices (Chatterton and Pickerill, 2010). Pickerill and Chatterton (2006) describe benefits of documenting and communicating autonomous struggles:

Collecting, preserving and talking about collective memories of previous struggles across times and spaces is the lifeblood of autonomy, providing

\footnotetext{
${ }^{4}$ Autonomy (literally: self-legislation) does not mean a rejection of social organization, but rather a rejection of oppressive governance (Castoriadis, 1991).
} 
sociospatial reference points for projecting autonomous visions into the present and future (ibid: 735).

This creation of autonomous visions or 'futures in the present' (Cleaver, 1979) allows new ways of living to be experimented with (Mann, 1986). Chatterton and Pickerill (2010) suggest that this experimentation is basically a utopian vision.

As stated above, Climate Camp Aotearoa is part of the global climate justice movement that originated from the global justice movement and has comparable goals and organizational processes. It is therefore logical to explore the role of Climate Camp Aotearoa through autonomous geography discourses.

\section{Aim and objectives}

The aim of this research is to explore the contribution of Climate Camp Aotearoa to the politics of climate change in Aotearoa, using autonomous geography discourses.

The research objectives that will support answering the aim of this thesis are:

- To explore motivating factors encouraging climate activist's involvement in Climate Camp Aotearoa.

- To examine key factors differentiating Climate Camp Aotearoa from other climate-focused groups and organizations in Aotearoa.

- To explore the contribution of Climate Camp Aotearoa to the creation of alternative futures in the present.

These aim and objectives are fulfilled by an in-depth literature review and field research which consists of one-on-one semi-structured interviews with 15 climate activists who have been involved in Climate Camp Aotearoa for six months or more.

In utilising a scholar activist epistemological lens which has been informed by feminist geographies, positionality and reflexivity are integral in each step of the research process. In line with Chatterton, Hodkinson and Pickerill's (2010) principles of scholar activism 
outlined above, this research is committed to social change and is an attempt to academically engage with radical discourses from within a tertiary institution. As a scholar activist I also wish to produce non-academic research outputs for participants in Climate Camp Aotearoa to use, as discussed further in Chapter Three.

\section{Contribution to academic literature}

This thesis is being undertaken in the Environmental Studies programme at Victoria University of Wellington (VUW), Aotearoa. Environmental Studies sits within the School of Geography and Earth Sciences, which includes human geography and development studies.

Contemporary Environmental Studies discourses are interdisciplinary (Soule and Press, 1988), including foci as diverse as:

[...] ecology, political science, ecological and natural resource economics, environmental history, environmental policy, energy pollution chemistry, environmental law, and environmental philosophy (ibid: 341).

As an interdisciplinary subject, Environmental Studies at VUW has strong ties to human geography and development studies. This thesis benefits from these links: human geography epistemologies and discourses are the basis of this research. VUW postgraduate students from Environmental Studies, Development Studies and Human Geography regularly produce politically motivated theses (eg: Lawrence, 2006; Turner, 2007; Hutchings, 2002). This thesis sits within a diverse academic context of politically motivated research and attempts to contribute new methods of academic analysis and engagement.

To my knowledge, no prior research undertaken in Aotearoa has explored autonomous geographies. Therefore, this research is unique in initiating the utilization of these discourses in Aotearoa and potentially offering a foundation for future research. This thesis primarily draws on autonomous geographies (eg: Chatterton and Pickerill, 2010; 
Pickerill and Chatterton, 2006; Routledge, Cumbers and Nativel, 2007); various academic discourses concerning politics and activism (eg: Day, 2004; Juris, 2008; Gibson-Graham, 1996; Gibson-Graham, 2006; Swyngedouw, 2008; Swyngedouw, 2010); and social movement theorists (eg: James, 1997; Maddison and Scalmer, 2006).

Secondly, there is relatively little research undertaken on recent activism in Aotearoa. This research will contribute to a body of literature on activism in Aotearoa by capturing the socio-spatialities of a unique activist collective: Climate Camp Aotearoa.

\section{Thesis structure and outline}

The national context of this research is established in Chapter Two. A brief history of activism in Aotearoa is described and the current national political context of climate change and activism is outlined. The intention of Chapter Two is to historically contextualise Climate Camp Aotearoa within national and international politics and to contrast autonomous politics with what has come before.

Chapter Three sets out the methodology followed in this research. As mentioned above, this research was carried out using a scholar activist epistemological lens, a lens which has been highly influenced by feminist geography discourses. Positionality and reflexivity are therefore incorporated into all areas of the research process. The secondary data collection point consisted of an in-depth literature review. The primary data collection consisted of one-on-one semi-structured interviews with 15 participants in Climate Camp Aotearoa. Interviews focused on research participants' motivations, the differences between Climate Camp Aotearoa and other climate-focused groups in Aotearoa New Zealand, and the alternative futures research participants feel they are working towards. This interview data was coded for key themes and is presented in Chapter Five. Lastly, limitations of this research are also described in this chapter.

The literature review (Chapter Four) examines academic literature pertaining to autonomous geographies and aims to ground this research within related discourses. A context of geographical discourses concerning politics and activism is outlined and a 
thorough review of autonomous geographies is offered. Areas of particular focus are then described: alternative futures; everyday activism; Global Justice Networks; a logic of affinity; direct democracy processes; direct action; activist politicization; community and emotions

The data collected from semi-structured interviews with fifteen long-term participants in Climate Camp Aotearoa is presented in Chapter Five. This chapter presents the eight key interlinked and overlapping themes that arose from the coding. These themes are: the 'bigger picture'; community; hope; direct democracy processes; direct action; politicization; and alternative visions. Excerpts from interviews supporting these themes are included with as much context as possible in an effort to limit misrepresentation of research participants.

Chapter Six is a discussion of the coded data from within the context established by the historical and political background (Chapter Two) and the review of associated academic literature (Chapter Four). This discussion is founded on the scholar activist epistemological lens discussed in the research methodology (Chapter Three) and builds a picture of the contribution of Climate Camp Aotearoa, as an autonomous geography, to the politics of climate change in Aotearoa.

Conclusions and recommendations for further research are laid out in Chapter Seven. I return to the research aim and objectives by revisiting the main themes of the critical discussion (Chapter Six). I reflect on the effectiveness of the scholar activist epistemology used and the contribution of this research to Climate Camp Aotearoa. Finally, I suggest areas for further development and research that have arisen from this thesis. 


\section{Chapter Two}

\section{Contextualizing Climate Camp Aotearoa}

If the streets were full, that was good. But full or empty, activism seemed to be a worthwhile, even pleasurable endeavour. It gave the lives of our informants meaning. It was engraved into their being. It could not be sloughed off, even when hard times seemed to loom. (Maddison \& Scalmer 2006: 248).

\section{Introduction}

This chapter contextualizes this research by situating Climate Camp Aotearoa historically and politically in Aotearoa. I present a brief history of national social movements and activism and overview current national activism and the political framework within which current activism operates. It is worth noting that there are minimal publications focused on recent activism in Aotearoa. Thomas' (2008) thesis on Left ${ }^{5}$ social movements has been extremely helpful in providing a cohesive basis for discussing historical activism in Aotearoa.

The global climate justice movement, as discussed in the Introduction, grew out of the global justice movement. Many movements within the global justice movement have strong foci on social justice issues and resistance to neoliberal and capitalist processes. Therefore, this overview will briefly outline Leftist social movements and activist events relating to both social justice and environmental justice.

\section{Early resistance to colonization}

Current Aotearoa society is founded on a history of violent colonization. There was significant Maori resistance to colonization and the resulting extensive confiscation of Maori land (Saunders, 1896). The eventual outcome of colonization and resistance was the Land Wars (Hutchinson, 1916). Much historical and contemporary Maori activism is

\footnotetext{
5 'Left' can be broadly considered as "supporters of Labour, Democrat and Green parties, the unions and community groups and unaffiliated progressive opinions” (McKnight, 2005: 15).
} 
a direct result of the signing and subsequent dishonouring of Te Titiri o Waitangi ${ }^{6}$ in 1840. This included extensive confiscation of land and the erosion of Maori social structures (Walker, 1983).

The peaceful resistance that occurred at Parihaka, Taranaki, in the 1870's and 1880's is a historic national narrative (Scott, 1954) that continues to inspire both Tauiwi ${ }^{7}$ and Maori activists today. The Parihaka community developed peaceful forms of resistance such as continuing to farm confiscated land and pulling out surveyor's pegs (Scott, 1954). These acts were countered aggressively by government militia and led to further protest (Sinclair, 1973).

\section{Early conservation}

There is indirect evidence of early Maori conservation tikanga ${ }^{8}$ (Taylor, 1974). Maori were directly reliant on local environments and a significant part of this relationship was the view that the land, the people and the gods were all interconnected (Taylor, 1974). Thus, Maori identity was intrinsically connected to the land. This relationship is manifested through concepts of mana whenua ${ }^{9}$ and kaitiakitanga ${ }^{10}$ and in food gathering and harvesting through principles of wairua ${ }^{11}$, mana ${ }^{12}$ and tapu ${ }^{13}$ (Young, 2004).

Despite Maori conservation practices, many avian species became extinct within two centuries of settlement (Pawson and Brooking, 2002). European colonization resulted in far greater environmental degradation and transformation (Pawson and Brooking, 2002).

In the first forty years of colonization, a European settler preservationist ethic began to develop (Keenan, 2002) which may have been motivated by aesthetic, spiritual, ethical

\footnotetext{
${ }^{6}$ The Treaty of Waitangi

${ }^{7}$ Foreign people or non-Maori (Moorfield, 2005).

${ }^{8}$ Practices or culture (Moorfield, 2005).

${ }^{9}$ A strong historical and cosmological connection between a community and their territorial lands (Moorfield, 2005).

${ }^{10}$ A concept of guardianship, trustee (Moorfield, 2005).

${ }^{11}$ Spirit (Moorfield, 2005).

${ }^{12}$ Power, influence, status: a supernatural force in a person, object or place (Moorfield, 2005).

${ }^{13}$ Sacredness, protection and/or restriction (Moorfield, 2005)
} 
and/or patriotic reasons (Young, 2004). Maori perspectives were largely excluded from the attempts at conservation made by early European settlers in Aotearoa.

\section{The early labour movement}

Worker's rights were fought for early on in colonized Aotearoa: in 1840 a campaign for eight-hour days took place (Roth, 1974).

Key events in the early labour movement include: the formation of 'one big union' in 1912 (Trotter, 2007); the creation of the Labour party in 1916 (Trotter, 2007); and the resulting birth of the Trade Union Congress as a result of feelings of betrayal directed towards the Labour party (Belich, 1971).

Thomas (2008) suggests that the labour movement in Aotearoa is characterized by heavy involvement with the state and that police have commonly displayed violence in reacting to strikes and direct action ${ }^{14}$.

\section{Decades of protest}

The 1960's were a turning point for activism in Aotearoa: the Vietnam War was a key factor in the radicalization of a generation (King, 2003). In Aotearoa New Zealand, as was the case globally, a significant shift in consciousness took place, leading to a shattering of social norms and a challenging of traditional beliefs (Baxter, 1971). The country experienced several social movement campaigns in the 1960's and 1970's. Movements such as the peace movement and anti-apartheid were characterized by their successes, effective public mobilization, and utilization of a wide spectrum of tactics (Thomas, 2008).

In the 60's and 70's 'cycles of protest' occurred as the national parliament interchanged between National and Labour'-led parliaments (Thomas, 2008). New social movements

\footnotetext{
${ }^{14}$ Defined as protest action carried out with the intention to directly and actively impact a situation rather than appealing to established authorities (De Cleyre, 1912)
} 
flourished, particularly the peace movement, women's rights, anti-apartheid, Maori activism and environmentalism (Thomas, 2008).

\section{The peace movement}

The peace movement in Aotearoa began out of opposition to nuclear weapons in the 1950's (Clements, 1988). The movement intensified in reaction to the National-led government offering military support to the United States in Vietnam (Clements, 1988), and was part of a global movement (Fyson, 1972).

Peace movement activists were subject to police violence and house raids (Locke, 1992), but the movement continued with new targets of a United States military base in the Southern Alps (Fyson, 1972), nuclear ships and French nuclear tests in the Pacific. The declaration of Aotearoa as 'nuclear free' was a victory for the peace movement in 1984 (Clements, 1988).

\section{The anti-apartheid movement}

The anti-apartheid movement opposed Aotearoa's rugby team playing with South Africa's rugby team during apartheid (Pringle, 2002). In 1960 an All Black tour of South Africa excluded Maori players, which lead to general public objection in Aotearoa New Zealand and resulting petitions and protests led to tours being cancelled in 1967 and 1973 (Pringle, 2002).

The anti-apartheid movement rekindled protest and activism in Aotearoa (Fyson, 1973) and led to the creation of national groups fighting racism (Richards, 1999). In 1981 mass sustained protests met violence from both rugby fans and police (Fyson, 1973). Both opposition to apartheid and the Vietnam War popularized direct action tactics in Aotearoa (Boraman, 2007). Experienced peace and anti-apartheid activists would later share these techniques with communities confronting environmental destruction.

\section{Maori activism}

As a result of increasing urbanization of Maori, racism became increasingly apparent 
during the 1960's and 70's (Sharp, 1997). Discrimination affected many factors for Maori, including employment and access to public services (Newnham, 1989). Maori resistance confronted implementation of the Treaty of Waitangi, Tino Rangatiratanga ${ }^{15}$, the land and Maori identity (Walker, 1983).

Radical activists deployed hikoi ${ }^{16}$, demonstrations and occupations (Sharp, 1997) and international links were made with indigenous activists (Sharp, 1997). The 1975 hikoi led by Dame Whina Cooper (Walker, 1992) and the 507 days of occupation at Bastion Point in 1977 were notable events. Despite continued police aggression and negative reactions from the state, further occupations and increasing mobilization occurred (Vasil, 2000).

\section{The feminist movement}

It was not until the 1970's and the second wave of feminism that oppression by patriarchal cultural institutions began to be addressed in Aotearoa (MaCaskill, 1976). Tactics employed by the feminist movement included feminist conferences, letter writing, lobbying, petitions and creative protests (Dann, 1985).

In 1979 feminism in Aotearoa as large-scale movement collapsed due to internal arguments (Dann, 1985). While no longer a radical movement, smaller-scale women's rights activism continued, as did organizations such as Women's Refuge.

Maori feminists have critiqued the second wave "white feminist ${ }^{\text {'17 }}$ movement in Aotearoa, stating that it was unreceptive to the inclusion of indigenous perspectives (Pihama, 2001) and ignored the contribution of Pakeha ${ }^{18}$ women to colonization (Hoskins, 1997). Because of this, many Maori feminists broke away and formed Maori women's groups (Pihama, 2001).

\footnotetext{
${ }^{15}$ Self-determination (Moorfield, 2005)

${ }^{16}$ Literally 'a walk' (Moorfield, 2005), specifically: a protest march.

17 'White feminisms' describe feminist discourses not created by women of colour, or indigenous women. White feminisms claimed gender as the main source of oppression, not accounting for race or class (Smith, 1992).

${ }^{18}$ New Zealander of European descent (Moorfield, 2005).
} 


\section{The birth of environmentalism}

Conflicts regarding management of native forests heralded the emergence of contemporary environmentalism in Aotearoa during the 1950's (Keenan, 2002). 'Environmentalism' and 'conservationism' are distinct concepts: the concept of conservation has existed for centuries as protecting and defending nature, while environmentalism has a more extensive context and may encompass conservation (Young, 2004). Environmentalism has been suggested to be more radical than conservationism (Young, 2004).

The public of Aotearoa became increasingly concerned over issues of exploitation and resource exhaustion (Keenan, 2002) and the term 'environment' became part of Aotearoa's colloquial vocabulary (Young, 2004). For most of the twentieth century the state had carried out the majority of significant conservation and it was not until the 1960's that the state became a target for conservationists and environmentalists (Keenan, 2002).

Native Forest Action Council was founded in 1975 and coordinated an extensive public campaign against native logging, primarily through public meetings, petitions and letter writing, with one significant direct action (Keenan, 2002). This campaign led to victories such as a moratorium on native logging in the North Island and the protection of many West Coast forests (Keenan, 2002).

The first major post-war environmental campaign opposed hydroelectric dam levels at Manapouri and Te Anau lakes in the South Island (Keenan, 2002). The Save Manapouri Campaign was described as a:

[...] phenomenon in public awareness, concern and agitation...It was nothing short of a colossal effort - letter writing, submissions, brochures, deputations, meetings, marches, street rallies, displays, fund raising ventures, networking, media publicity, and petitions that must have put the fear of the ballot box into the politicians (Peat, 1994: 3). 
Dann (2002) suggests that the environmental movement in Aotearoa has been shaped by colonialization, industrialization and modernization and that for Maori the "process of environmental colonization is still being contested" (Dann, 2002: 321). Dann indicates that the environmental movement has not allowed space for indigenous perspectives to be included.

\section{Resistance to neoliberalism}

In the late 1970's National Prime Minister Robert Muldoon's 'think big' strategy led to resistance from workers and industrial action (Trotter, 2007). Worker strikes became frequent and resistance met with state violence and a conservative backlash (Boraman, 2007). In the 1980's the fourth Labour government used this 'crisis atmosphere' to initiate comprehensive neoliberal reforms (Quiggin, 2001), led by Roger Douglas. Despite extensive privatization, market deregulation, phasing out of government subsidies, and eventually welfare reductions (King, 2003) there was minimal organized resistance against neoliberal processes (Kelsey and O’Brien, 1995).

Author Nicky Hager considers neoliberalism the reason for minimal social movements in the 1980's and 90's. He suggests that neoliberalism has eroded the country's left and activist circles (in Thomas, 2008).

Kelsey (1995) believes the only resistance to neoliberalism has been by Maori activists, while Boraman (2007) offers autonomous resistance in the 1980's and 90's by poverty action groups and community mobilization against the closure of public amenities (Boraman, 2007).

\section{Activism in the early $21^{\text {st }}$ Century}

Three primary foci of national activism in the early $21^{\text {st }}$ century were: the opposition to the Iraq War; the resistance to the release of genetically modified organisms (GMOs) in Aotearoa; and resistance concerning a proposed mine in Happy Valley. All were national movements linked with international movements and had significant public support. 
Anti-war sentiments became increasingly widespread in Aotearoa in the early half of the 2000's, with ongoing large-scale rallies, direct actions and media communications (eg: Peace Action Wellington, 2005). Groups such as Peace Action Aotearoa and Peace Action Wellington highlighted the Government of Aotearoa's role in providing military intelligence to the United States (ibid).

From 1999-2008 heavy debate concerning GMOs occurred between environmental groups, sectors of the scientific community and the public. A diverse group of people opposed to GMOs employed tactics such as: direct action (Eden, 1999); pickets (NZPA, 1999); vandalism and Molotov cocktails (Ministry for the Environment, 2008); protest marches and a low level public boycott (Hamed, 2008). While the commercial GMO moratorium was eventually lifted, some campaigners consider that an increase in public awareness has created long-term victories (Hamed, 2008).

Maori opposition to GMOs was also strong, founded on concerns such as the protection of Titiri o Waitangi rights, cultural practices, beliefs and values (Hutchings, 2002).

The Save Happy Valley Coalition drove a significant national environmental campaign of the early 21st century in Aotearoa: Save Happy Valley. This coalition was created in April 2004 to protest against a proposed Solid Energy opencast mine in Happy Valley, on the West Coast of the South Island (Save Happy Valley, n.d.). An extended occupation took place until 2010, when activists were trespassed from the site (Save Happy Valley, n.d). The core campaign utilized horizontal decision-making, civil disobedience and direct action (Save Happy Valley, n.d.).

\section{Operation 8}

The 'Operation 8' police raids of October $15^{\text {th }} 2007$ are highly significant in the history of activism in Aotearoa. More than 300 paramilitary police raided homes of political activists across the country, making 18 arrests overall (Goldman, 2007). The warrants 
were the first time the Terrorism Suppression Act (2002) (TSA) was invoked in a search warrant (ibid).

The arrestees were active in Tino Rangatiratanga, anarchist, peace and environmental issues (Goldman, 2007) and the raids were the result of surveillance lasting 18 months. The majority of the arrestees were Tuhoe, an iwi that has never signed Te Titiri Waitangi and has a strong history of actively working towards Tino Rangatiratanga (Masters and Gower, 2007).

While the TSA charges were eventually dropped due to insufficient evidence, 18 individuals arrested in connection with the October $15^{\text {th }}$ raids have been awaiting trial for more than three years, facing multiple charges and potential prison sentences under the Arms Act (Goldman, 2007). The consequences of Operation 8 have been severe for the arrestees, their families and friends, and politically active communities (Morse, 2008). Operation 8 has affected the political involvement of the arrestees, who were often influential figures in their communities both personally and politically (Morse, 2008). The effects on political activism resulting from Operation 8 are unknown, but this severe state reaction to political activity may have long-lasting influence in discouraging radical activism in Aotearoa.

\section{Current context of activism}

Despite state repression, activism continues in Aotearoa. At the time of research the National Party is leading the government of Aotearoa, and a variety of individual and collective struggles exist.

In the first half of 2010 widespread public activism became re-normalized as large marches occurred around the country with the aim of protesting against mining on Schedule 4 conservation land (NZPA, 2010). The result was an announcement that mining on Schedule 4 lands would not proceed (Greenpeace, 2010).

Activists claim that there is an encroachment on the freedoms of the public of Aotearoa, due to bills such as the Search and Surveillance Bill (Stop the Search and Surveillance 
Bill, n.d). In 2010 a group called Stop the Search and Surveillance Bill were active in their opposition. They argue that this bill furthers the powers of the state and government agencies and limits political activity (ibid).

Neoliberalist processes continue to be challenged by collectives and coalitions such as the TPP Action Group, a group formed to resist Aotearoa signing up to the Trans Pacific Partnership Agreement: a trade and investment agreement which will include Aotearoa, multiple pacific nations and the United States (TPP Action Group, 2011).

Maori activism and the fight for Tino Rangatiratanga continue within a context of continued colonization. The Seabed \& Foreshore has been an issue since June 2003, when the Court of Appeal ruled that Maori were entitled to seek 'customary title' over sections of the foreshore and seabed in the Maori Land Court (Young, 2006). There has been ongoing political debate about this issue. Actions include a hikoi on the 5th of May 2004 which was estimated to contain fifteen thousand people by the time it reached Parliament (Sharples, 2006).

\section{Current action on climate change}

Aotearoa has a unique place in the international struggle to tackle climate change. The government has put into place an Emissions Trading Scheme (NZETS) that environmental non-governmental organization (ENGO) Greenpeace Aotearoa's political advisor has described as:

[...] a pathetic ETS which won't actually do anything to reduce emissions (Keey in Fallow, 2009).

The NZETS is a national, all-sectors, all-greenhouse gases scheme first legislated in 2008 and amended in November 2009 (Smith, 2009). The NZETS has been widely criticized by environmentalists and political commentators for the late-entry of agriculture into the scheme, phase-out of free units and the high cost to the taxpayer (Brendish, 2010; Woodham, 2010; AAP, 2010). 
There are a number of ENGOs and community organizations that are active on climate issues. Greenpeace Aotearoa is one of the most noticeable: their 'SignOn' campaign in 2009 encouraged over 230,000 people to support an emissions reduction target for Aotearoa (Greenpeace, n.d.).

350 Aotearoa is a prominent community-led organization part of the 350.org international movement founded by author Bill McKibben. The aim of 350 Aotearoa is to inspire communities to act on climate change (350 Aotearoa, n.d.). Largely youth-led, 350 Aotearoa lobbies politicians with the aim of tackling climate change in a positive, creative and fun manner through festivals, photo opportunities and community events (ibid).

Transition Towns is an international initiative that provides community education and support in response to the threats of climate change and peak oil (Rudningen, 2009). Through offering practical steps to living more sustainably and a supportive social context, Transition Towns aims to empower community action (ibid). Built on a philosophical understanding of permaculture (Holmgren, 2007), there are currently a number of Transition Town communities established in Aotearoa (Rudningen, 2009). Rudningen (ibid) suggests that Transition Town initiatives encourage the adoption of proenvironmental behaviours.

There have been an increasing number of climate justice-focused groups emerging in the last three years, including Climate Camp Aotearoa. Other climate justice-focused groups include Coal Action Network Aotearoa (CANA) a national collective focusing primarily on Southland lignite extraction issues.

Resistance to oil and gas exploration and harvesting is growing. On the East Cape of the North Island local community groups have become increasingly active. In April 2011 a flotilla opposing the resistance of Brazilian oil giant Petrobras traveled from Auckland to the site of the proposed drilling (NZPA, 2011). In Taranaki, Climate Justice Taranaki is 
working to oppose further gas exploration from a climate justice perspective (eg: Climate Justice Taranaki, 2011). Many of these climate justice focused groups have links to Climate Camp Aotearoa through previous Climate Camp Aotearoa participants.

\section{Summary}

The history of activism and social movements in Aotearoa has been rich and complex. This chapter has outlined major events and summarized key social movements with the aim of providing a current and historical context for this research. There was significant Maori resistance to European colonization and its results, with peaceful resistance at Parihaka being one of the most well known occurrences. Conservation practices were carried out early on by both Maori and Pakeha, though Maori perspectives were largely excluded from Pakeha conservation attempts. Overall, historical activism in Aotearoa has resulted in police aggression, and the labour movement in Aotearoa has been characterized by heavy involvement with the state. A characteristic of Maori resistance has been continued or renewed protest as a reaction to state and/or police violence.

Social movements of the 1960's and 1970's were characterized by their successes, effectively mobilizing large sectors of society and utilizing a wide spectrum of tactics in the peace movement, anti-apartheid movement, environmentalist movement and Maori protest movement. However, both internal factions and a marginalization of indigenous perspectives eventually fractured the feminist movement.

In the late $20^{\text {th }}$ century the rise of neoliberalism is considered to have negatively impacted activism in Aotearoa, not including Maori activism. In the early $21^{\text {st }}$ century opposition to the Iraq War and opposition to the national release of GMOs mobilized large groups of people. Save Happy Valley was a notable, if unsuccessful environmental campaign of the 2000's. 'Operation 8' was a highly significant event targeting political activists in Aotearoa. These police raids have resulted in severe and ongoing consequences for the arrestees and potentially severe consequences for politically active communities and individuals. 
Current and recent national activist foci include: mining, the Trans Pacific Partnership and the seabed and foreshore. Current action on climate change mainly consists of Greenpeace Aotearoa, 350 Aotearoa, Transitions Towns, CANA and a number of active climate justice groups opposing fossil fuel extraction in Aotearoa. 


\section{Chapter Three}

\section{Research Design and Methodology}

Our goal as academics was still to understand the world in order to change it, but with a poststructuralist twist - to change our understanding is to change the world (GibsonGraham, 2008:3).

\section{Introduction}

The purpose of this chapter is to describe the methodology and research design used in this thesis. As established in the Introduction (Chapter One), the overarching aim of this research is to explore the contribution of Climate Camp Aotearoa to the politics of climate change in Aotearoa, using autonomous geography discourses. This chapter presents a framework for answering this aim and associated objectives through a scholar activist epistemological lens.

The context for scholar activism is set out, beginning with a brief description of feminist geographies, a highly influential field. The principles and applications of scholar activism are then examined, and my positionality throughout the research process is explored. Lastly the qualitative methods utilised in this research are described and potential limitations outlined.

\section{Feminist geographies}

Feminist geographies apply feminist theoretical discourses and methodologies to the study of society, space and the human environment (Rose, 1993). Feminist geography is not simply a sub-discipline of geography: rather it contributes to wider postmodern, critical theory approaches. Feminist geographers often but not exclusively focus on gender divisions within geographical discourses (McDowell, 1993).

Feminist geographies have offered a critique of the ways in which various disciplines reinforce gender divisions and perpetuate an academic bias of masculinity (Moss, 2007). 
Within human geography, Rose (1993) has critiqued peer-reviewed geographical journals for framing the landscape as a subordinate feminine. This assumed separation of people from their environments works in parallel with the supposed separation of mind and body: a key normative challenge by feminist geographers (Johnston and Sidaway, 2004).

To combat conventional patriarchal approaches, postmodern and poststructuralist feminist geographers have attempted the formulation of alternative geographical discourses that rebuild theories, epistemologies, subjects and politics (Rose, 1993). In doing so feminist geographers have focused on subjectivity in contrast to objectivity, often concentrating on experiences of individuals or collectives in their own localities, instead of empirical research located in distant spaces (ibid).

A key development in feminist geographies has been a dialogue concerning who benefits from research outcomes and publications (Gregory, Johnston, Pratt, Watts and Whatmore, 2009) and an acknowledgement of the intrinsic power relations between researcher and researcher (Farrow, Moss and Shaw, 1995).

A feminist geography viewpoint encourages researchers to write and interact on a political rather than simply academic level: creating social change is often a parallel commitment to the creation to feminist knowledge (Rose, 1993).

Feminist geography tools used by scholar activists include: a focus on positionality, considering whom the research benefits, and encouraging collaborative research (Farrow, Moss and Shaw, 1995; Nast 1994). Constant reflexive engagement by the researcher allows confrontation with hegemonic replication within the research process (Farrow, Moss and Shaw, 1995). These research tools have been incorporated into many disciplines. The scholar activist epistemological framework used in this research has been highly influenced by feminist geographies and implements a number of the methodological processes described above. 


\section{Scholar activism}

Critical geographies focus on actively engaging with relationships of power and resistance (Gibson-Graham, 1996; Gilbert, 1994). Scholar activism is a field within critical geography that describes a dual identity of both activist and scholar. Chatterton, Hodkinson, and Pickerill (2010) suggest that the conscious combination of academic work with personal politics is uncommon within geography and that it is rare for academics to be politically active in the social movements they study. Scholar activists have reacted to this dearth by recording and examining their critical engagements as both academics and activists (ibid).

What unites past and present generations of scholar activists is their desire to bring together their academic work with their political ideals to further social change and work directly with marginal groups or those in struggle. This work goes beyond simply trying to understand the politics of our research and argues that our work is political. (ibid: 427)

Thus, scholar activism consists of a fusion between academic work and personal politics and political involvement. Chatterton, Hodkinson and Pickerill, (2010) are arguing that, for scholar activists, academic work must not only critique or theorise from a scholar's perspective, but must also be informed by scholar's own politics and a direct involvement with social movements. This aligns with my personal motivations for documenting and exploring Climate Camp Aotearoa as an embedded participant.

Routledge (1996) has proposed that the boundaries between academia and activism could be explored and disrupted by the use of a fluid 'third space'. He describes this third space as a place of praxis where theory is lived out in the present (ibid). In creating this space to write within resistance, Routledge (ibid) is locating the scholar activist.

As indicated in Figure 1 (below), scholar activism blurs boundaries between academia and activism. Chatterton, Hodkinson, and Pickerill (2010) argue that the separation 
between academia and wider society as locations of struggles and knowledge is false but continues to exist, and that therefore scholar activists must recognize and minimize it.

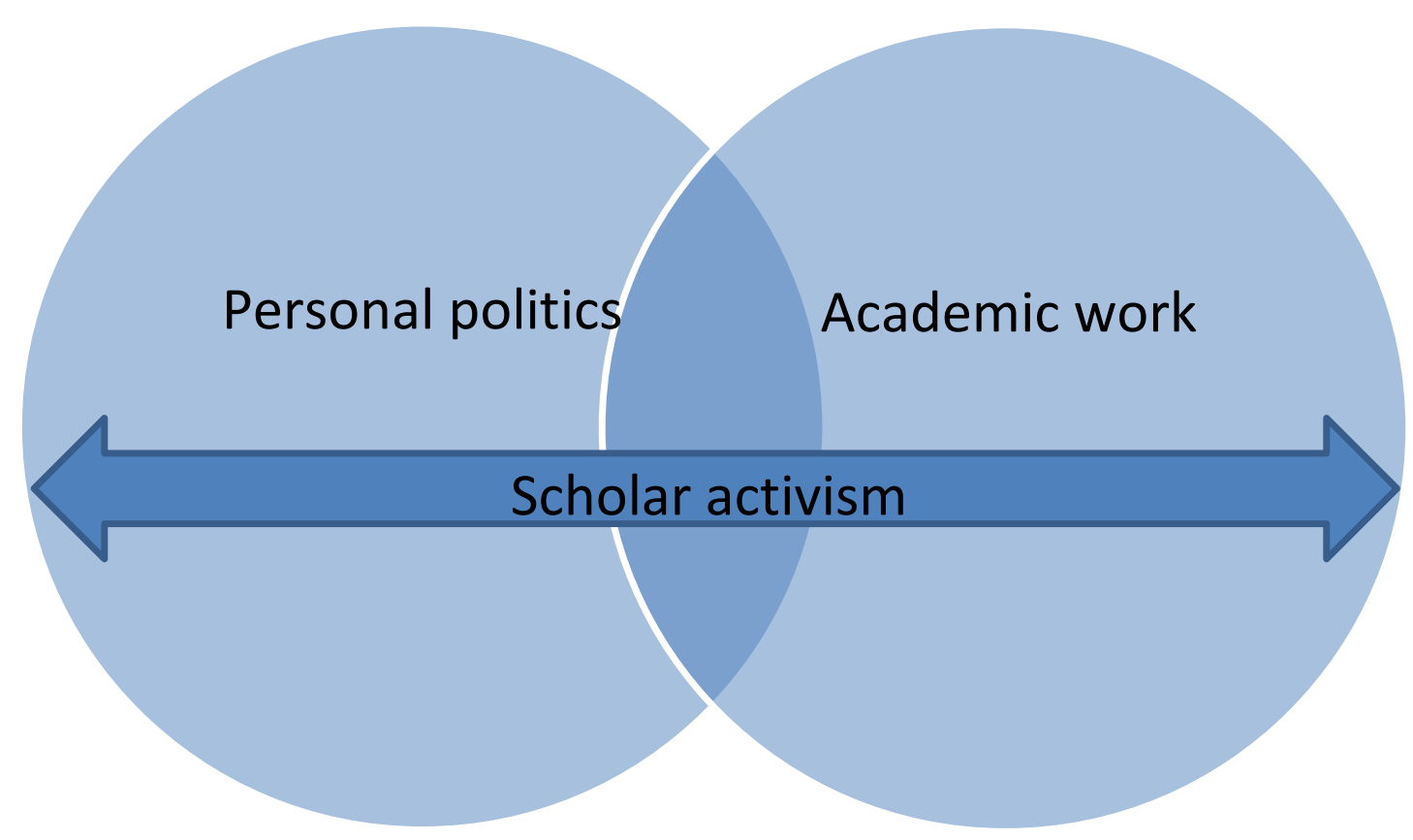

Figure 1: Scholar activist epistemological framework

Chatterton, Hodkinson, and Pickerill (2010) suggest seven guiding principles towards a strategy for scholar activism. The principles are as follows:

1. Work in and against the neoliberal university.

2. Recognize the powerful potential of research, publishing and educating.

3. Be involved in creating a global knowledge commons.

4. Be aware of the impacts of action research.

5. Organize with fellow scholar activists in collective action networks.

6. Be the change we want to see.

7. Intervene strategically and collectively in ways that are accountable and useful to social movements. 
While I have attempted to follow the guiding principles above to the greatest extent possible, as a candidate for a Masters degree in Environmental Studies from Victoria University of Wellington, parameters and practice are limited in that I have time constraints for carrying out this research. For example, I was unable to approach this research from a 'collective action network' instead of utilizing individualized research processes.

This research is committed to social transformation and is an attempt to engage with radical discourses from within academia. As an embedded researcher, I have deliberately combined my academic work with my personal politics in exploring a section of a social movement I am involved in.

While I acknowledge that my research must meet certain academic criteria to achieve a Master's Degree in Environmental Studies, the intention to benefit Climate Camp Aotearoa and enhance climate activism within Aotearoa has also been a significant driver in the completion of this thesis. To this end I have created a non-academic research output in collaboration with Climate Camp Aotearoa participants. I hope that this research output will contribute to the aims and objectives of Climate Camp Aotearoa and national climate activism as a whole. This colloquially worded booklet is discussed at depth in the concluding chapter of this thesis (Chapter Seven).

The constant negotiation between activist and academic identities and spaces is a difficulty that activist scholars must face throughout the research process (Chatterton, Hodkinson, and Pickerill, 2010). Therefore, continual reflexivity has been a significant tool throughout the research process of this thesis. This reflexivity and my position as researcher are outlined below.

\section{Positionality and reflexivity}

Positionality and reflexivity are significant tools for scholar activists to explore positions and identities not usually incorporated into academic research, and to allow negotiations 
and disruptions between the boundaries between activism and academia (Chatterton, 2008).

Feminist geographers have recognized complex relationships between the personal, political and the textual and have connected them to issues of representation and positionality (Rose, 1995). Positionality is a significant consideration in fields where knowledge is treated as situated rather than objective (Rose, 1995). The concept of positionality draws on factors of identity, the ways in which these factors relate to society and the inherent power dynamics (Chacko, 2004). As Cook et al. (2005:5) states: “it's impossible to be "impartial"'.

The relationship between researcher and research participants has historically been one of power and domination (Rose, 1995). From the view point of colonized peoples, for example, research is "inextricably linked to European imperialism and colonialism" (Smith, 1999:1). Therefore, feminist geographers have called for not only an examination of the researchers own identities, but also analysis of the relationship of these identities to intuitional, geopolitical and material situating factors (Nagar, 2002).

In accordance with a scholar activist epistemology, I recognise that my position as a researcher is subjective and that my background and personal characteristics impact significantly on data collection and analysis. I position this research from the perspective of a white, Tauiwi woman pursuing higher education in Aotearoa New Zealand; a descendent of colonisers living a colonized country.

Routledge (1996:401) argues that we "write ourselves as particular kinds of subjects". I write myself as a postgraduate student who is politically active and is conscious of using a privileged academic voice.

I have attempted to represent the research interviewees as fairly and accurately to the best of my ability; however the final responsibility of this thesis rests fully on me. I will ultimately receive more benefits from this thesis than anyone else. 
I have been an active participant in Climate Camp Aotearoa since April 2009. Throughout this research I have engaged and collaborated with the collective in ways which blur the boundaries between research and activism. I have found that being both researcher and activist has led to feelings of being torn between worlds Chacko (2004) suggests often arises in fieldwork. Struggling with this fractured 'insider/outsider' identity has been a continual process throughout this thesis work. I acknowledge that my prior relationships and friendships with the research participants has both benefited and potentially complicated my research.

Reflexivity is a method of incorporating positionality into research in a way that challenges traditional concepts of objectivity (England, 1994). Reflexivity is to:

[...] reflect self-consciously on your research, to question one's own assumptions and to work to make your values an explicit part of the process (Tolich and Davidson, 1999: 23).

By using active and critical reflexivity, academics are ideally empowered to creatively and proactively confront established power relationships instead of replicating existing hegemonies (Maxey, 1999). Researchers must also be aware of problems with reflexivity: it is problematic to infer that researchers are able to remain completely aware of their self-conscious while challenging power relationships (Rose, 1997).

Askins (2009) acknowledges the importance of emotion for activist geographers. She argues that the emotions of both the researchers and research participants must affect the choice of research methodology and the dissemination of research and calls for emotional transparency and reflexivity in the research processes (ibid).

Reflexivity infers that researchers must be aware of our own worldviews and those of others (Rose, 1997). For the reasons outlined above, I have made a conscious decision to be actively and continually reflexive throughout this research process, including acknowledging my emotions. 


\section{Method}

Data collection for this thesis is qualitative, consisting of an in-depth literature review and semi-structured interviews with 15 research participants. As discussed earlier in this chapter, scholar activist and feminist geography research tools are applied to both data collection points with the aim of building up a picture of the contribution of Climate Camp Aotearoa to the politics of climate change in Aotearoa, using autonomous geography discourses.

\section{Secondary data collection: literature review}

A literature review (Chapter Four) was carried out to ground this research within international academic discourses. Geographical context concerning politics and activism is outlined and an in-depth review of autonomous geographies and pertinent fields is carried out. Literature reviewed is primarily from the fields of autonomous geographies, political philosophy and social movement theory. Particular focus is given to alternative futures; everyday activism; Global Justice Networks; a logic of affinity; direct democracy processes; direct action; activist politicization; community; and emotions.

The information collected in the literature review allows for contextualized discussion of the primary data collected in semi-structured interviews with long-term participants in Climate Camp Aotearoa.

\section{Primary data collection: semi-structured interviews}

One-on-one, in depth, semi-structured qualitative interviews were the chosen method of data collection for this research. A semi-structured interview uses an interview guide rather than a set of questions and allows researchers to obtain information of significant depth, while also encouraging the researcher to adapt the interview guide over time. This provides opportunities to engage reflexively, actively and critically (Tolich and Davidson, 1999).

Blee and Taylor (2002) suggest that semi-structured interviews offer: 
[...] the opportunity to discover the respondents experience and interpretation of reality and access to people's ideas, thoughts and memories in their own words rather than in the words of the researcher (Blee and Taylor 2002:89).

Therefore, research participants' quotes are examined within an expanded context of social discourse. This focus on subjective meaning is important within a scholar activist epistemological framework and is significant in terms of understanding how those participating in social movements understand and justify their involvement (Blee and Taylor, 2002).

The data collected from semi-structured interviews with fifteen participants in Climate Camp Aotearoa is presented in Chapter Five. This chapter presents the eight key interlinked and overlapping themes that arose from the coding. These themes are: the 'bigger picture'; community; hope; direct democracy processes; direct action; politicization; and alternative visions. Excerpts from interviews supporting these themes are included with as much context as possible in an effort to limit misrepresentation of research participants.

\section{Participant characteristics and selection}

15 people involved in Climate Camp Aotearoa were selected for this research. As an embedded active participant in Climate Camp Aotearoa, I was familiar with all research participants prior to data collection. Selection occurred through the snowball technique and participants were initially invited to take part in the research by means of email contact.

All participants had been involved in Climate Camp Aotearoa for six months or more. Interviews ranged from 30 minutes to over an hour, and were carried out in locations of the participants choosing. The participants ranged in age from 18 to 45 years old, with a gender ratio of six male participants and eight female participants. 


\section{Consent and ethics}

The Victoria of University Wellington Human Ethics Committee granted Ethical Approval for this research. All participants received information sheets (Appendix 3) and informed consent forms (Appendix 2). All data is considered confidential. Participants were informed that they could withdraw from the research up to eight weeks after the interview, and that they would have an opportunity to review their interview transcripts post-interview.

\section{Research journal}

As stated above, self-reflexivity is an important part of utilizing a scholar activist conceptual framework. Throughout the fieldwork experience I kept a field journal to document my experiences and reflections. This allowed me to analyze and adapt my interview guide and style as the research progressed. The journal also provided an important space for testing my assumptions and recording reactions and emotions brought up in the interviews.

\section{Data analysis: coding}

The interviews were transcribed to allow textual analysis. The transcripts were then coded, allowing me to organize the information gathered and identify themes, connections and inconsistencies. Coding allows researchers to categorize data by means of short hand techniques, providing an integral link between data collection and final conceptualization (Tolich and Davidson, 1999).

I used positive coding to indentify common themes and therefore indentify similarities, points of differences and potential underlying assumptions (Tolich and Davidson, 1999). Positive coding allowed me to flag interesting data and to suggest themes needing more input.

I read through the transcripts and created thematic files for specific topics depending on how often a topic was discussed. These thematic files often overlapped and connected in various ways. The files were digitally-created and tagged, and were re-read many times 
to allow me to fully assess the importance of what was being said and what was being avoided or marginalized.

In congruence with scholar activist and feminist geography epistemology I have attempted to let the participants' voices speak for themselves by including direct quotes with surrounding dialogue to provide context. I have also remained reflexive through the coding process, changing the interview guide as data inconsistencies or gaps have emerged.

\section{Limitations}

I consider potential limitations in this research minimized because of my long-term involvement in Climate Camp Aotearoa. As I was previously acquainted with all of the participants prior to conducting fieldwork, I invariably felt that interviewees were open and comfortable in discussing their backgrounds, thoughts and emotions. I believe that my knowledge of the history and context of Climate Camp Aotearoa allowed me insights that an outsider would not have been able to easily obtain.

I consider I avoided many of the research process pitfalls Chatterton, Hodkinson and Pickerill (2010) highlighted. While they were well-funded and established scholar activists, I am an unpaid, un-funded postgraduate student. This, I hope, has diminished the inequality of the power relations inherent in a researcher-subject relationship.

There is a possibility this intimacy could have negatively impacted my own interpretation and choices throughout the interview process, but this was mitigated through the use of continual reflexivity and considerations regarding positionality.

While I acknowledge that my prior relationships with the research participants may have unknowingly shaped my coding and analyzing of the data, I hope that through reflexive processes the impact of this has been moderated. 


\section{Summary}

This chapter describes the methodology and research design used in this thesis to fulfill the aim of exploring the contribution of Climate Camp Aotearoa to the politics of climate change in Aotearoa, using autonomous geographies. A scholar activist epistemological framework was used in carrying out this research, and I have implemented this framework as an embedded participant: deliberately combining my academic work with my personal politics. I have attempted to encourage radical discourses within academia; produced non-academic research outputs; and carried out research which is committed to social transformation. Positionality and reflexivity are key considerations in confronting power dynamics between those researched and the researcher, and I have made a conscious decision to be actively and continually reflexive throughout the research process.

Data collection for this thesis is qualitative; made up of a literature review and semistructured interviews with 15 participants in Climate Camp Aotearoa. Data was transcribed and coded to allow organisation of information and easy presentation. A research journal was utilised for the duration of the fieldwork to encourage active and continual reflexivity.

I consider that research limitations were minimised due to my 'insider' status as a longterm participant in Climate Camp Aotearoa. 


\section{Chapter Four}

\section{Literature Review}

What, for example, would politics be like if it were not directed to the attainment of certain goals, the coming to fruition of ideals or plans, but rather required a certain abandonment of goals? (Grosz, 1999: 11).

\section{Introduction}

In this chapter I present a literature review that draws on academic texts to ground this research within relevant international discourses, aiming to create an academic context for answering the aim of this research: to explore the contribution of Climate Camp Aotearoa to the politics of climate change in Aotearoa, using autonomous geography discourses. This chapter presents a foundation for all three objectives: exploring motivating factors encouraging involvement in Climate Camp Aotearoa; examining factors differentiating Climate Camp Aotearoa from other climate-focused groups and organizations in Aotearoa; and exploring the contribution of Climate Camp Aotearoa to the creation of alternative futures in the present.

Firstly, I present a contextual base for reviewing autonomous geographies by outlining geographical discourses concerning activism and politics. This context aims to place autonomous geographies within a discussion of the place of activism and dissent within society. The definition and history of autonomous geographies is then presented, with an acknowledgement of the location of this research within these discourses. Areas of particular interest in this research are laid out: alternative futures; everyday activism; global justice networks; a logic of affinity; direct democracy processes; direct action, activist politicisation, community; and emotions.

Autonomous geographies, critical geography, critical theory and the branch of sociology concerned with social movements are fields that are drawn on. Wherever possible I have attempted to utilize sources from Aotearoa, but these were often nonexistent. 
I acknowledge that literature reviewed has a distinct Anglo-American bias due to constraints of language and accessibility.

\section{Activism}

Routledge (2009) defines activism in the Dictionary of Human Geography as:

[...] the practice of political action by individuals or collectives in the form of social movements, non-governmental organizations and so on (Routledge, 2010: 23).

Maxey (1999) has proposed an alternative definition of activism that situates everyone as activists, suggesting that activism should include everyday thoughts and actions that challenge oppressive power structures. Routledge (1996) argues that this definition makes activism accessible to larger numbers of people and intrinsically connects activism and academia.

Activism confronts power dynamics (Routledge, 2010) and is therefore tightly linked to geographical discourses surrounding concepts of power and resistance. Building upon Foucault's view that power is fundamental in almost all relationships, critical geography discourses maintain that power is fundamentally part of all spatial practices and is always spatialized (Gregory et al. 2010). Thus, activism is considered as a dynamic and spatialized process. Cultural geographers have identified everyday activism that contest oppression and domination, discussed later in this chapter.

\section{Activism and politics}

This section of the literature review I will examine the place of dissent in democracy by exploring Swyngedouw's suggestions that our Western societies are 'post-political' and 'post-democratic' due to processes that displace dissensus and exclude and marginalize certain people and perspectives. 
These critical discourses state that genuine politics should be disruptive, transformative and without a single location (Swyngedouw, 2008). Swyngedouw (ibid) argues that not all activism is necessarily truly 'political':

Politics is] not about expressing demands to the elites to rectify inequalities or unfreedoms, exemplified by the demands of many activists and others who are choreographing resistance to the police order, but, in contrast, it is the demands to be counted, named and recognised as part of the police order (ibid: 21).

Swyngedouw is maintaining that activism must radically challenge societal processes, rather than simply offering resistance to them (ibid). Activism will be unable to undermine the processes of order when it is completely contained within established hierarchies (Zizek, 2002).

Swyngedouw (2010) has argued that the issue of climate change is commonly framed in a manner that depoliticises and removes dissent. While climate change is increasingly visible in Western societies and climate policies are given ever-increasing political weight, current climate policy aims to allow business-as-usual, aiming simply to introduce new technologies and governance which ensures that no major societal transformations will take place (ibid).

Environmentalists may confront the causes of climate change, but they largely continue to reproduce the liberal-capitalist order in the process (Swyngedouw, 2010) and thus are driven by a politics of demand. Swyngedouw suggests that environmentalist concepts such as 'sustainability' have contributed to depoliticised environments by externalizing dissensus and illegitimatising alternative socio-environmental futures (Swyngedouw, 2010). Therefore, climate activism cannot be considered effective or even genuinely political if it does not aim to transform the existing order.

From this perspective, reformist action on climate change must be considered depoliticised in that in aims to lessen the effects of climate change while avoiding 
societal transformation. Pickerill and Chatterton (2006) suggest that the issue of climate change demands the naming and creation of alternative futures.

\section{Autonomous geographies}

Autonomous geographies are defined as:

[...] spaces where there is the desire to constitute non-capitalist, collective forms of politics, identity and citizenship (Pickerill and Chatterton, 2006:730).

The concept of autonomous geographies was developed by activist geographers Pickerill and Chatterton (2006) in response to academic misunderstandings of the 'movement of movements'. They hypothesize that these misunderstandings are largely methods of organizing unfamiliar to academics (ibid).

Processes are often based on anarchist principles, founded on a belief that, as Holloway (2002) suggests, transforming and claiming state power reproduces the same power with new leaders. Taking into consideration these new rules of engagement, Pickerill and Chatterton (2006) argue that these new movements need new tools to effectively examine them, proposing that academics:

$[\ldots]$ use the concept of autonomous geographies to understand alter-globalisation movements as a progressive politics, not grounded through a particular spatial strategy but as a relational and contextual entity drawing together resistance, creation and solidarity across multiple times and places. (Pickerill and Chatterton, 2006: 2)

Groups can be described as striving towards autonomous geographies if they work towards: 
[...] personal freedom, a mistrust of power and a rejection of hierarchy, and the advocacy of self-management, decentralised and voluntary organisation, direct action and radical change. (Pickerill and Chatterton, 2006: 5)

Autonomy is best seen in terms of relationships of power, a tendency rather than a fixed state or possession (Castoriadis, 1991). Just as capitalist and post-capitalist processes can be seen as coexisting processes (Gibson-Graham, 2006) different spaces embody different levels of autonomy: autonomous geographies are simultaneously present with capitalist, neoliberalist and globalizing relationships of power. Thus, there is no clear line between autonomous and non-autonomous processes/spaces. Autonomous and nonautonomous geographies are constantly reconstructed through changing times and spaces (Pickerill and Chatterton, 2006).

Autonomous geography discourses are a relatively recent development within critical geography, and has therefore produced limited academic output from a limited number of authors. Autonomous geographies have not, to my knowledge, been previously applied within the context of Aotearoa. This research aims to fill this niche.

Documenting and communicating the socio-spatialities of autonomous struggles can inspire other collectives and groups to create their own alternative futures in the everyday (Pickerill and Chatterton, 2006). Chatterton and Pickerill (2010) described what is needed:

[...] detailed empirical accounts of the messy, gritty and real everyday rhythms as activists envision, negotiate, build and enact life beyond the capitalist status quo in the everyday (Chatterton and Pickerill, 2010: 481).

\section{Alternative futures}

The constant renegotiating between autonomous and non-autonomous geographies described is similar to Gibson-Graham's (2006) acknowledgment of capitalism and globalization as narratives constructed from many stories. Gibson-Graham (1996) articulate that post-capitalist processes are already part of the present, and therefore post- 
capitalist and capitalist politics are in a state of constant negotiation, which allows for the creation of alternative futures in the present. Gibson-Graham (2006) suggest that a postcapitalist vision must:

[...] be sustained by the continual work of making and remaking a space for it to exist in the face of what threatens to undermine and destroy it (ibid: xxvii).

These continually remade spaces are the locations where alternative futures are formed. The creation of alternative futures, enacted in the present, is necessary for healthy democracies (Swyngedouw, 2008).

These 'spaces of hope' (Harvey, 2002) are locations where new worlds are constantly built in the ashes of the old, but are necessarily messy, contested and complicated (Chatterton and Pickerill, 2010). Here activists must act and theorize in ways that are "simultaneously against and beyond the capitalist present" (Pickerill and Chatterton, 2010:475) and thus live between worlds: the existing world and world that is hoped for.

Autonomous geographies can be applied to understand how everyday life and actions combine to create alternative futures.

Swyngedouw (2008) suggests that to allow room for alternative visions of the future, spaces of the political must be reclaimed. He argues that practices aiming to replace the post-political require space to create symbolic geographies of their own. Space should allow experimentation with radical democratization and to vocalize new symbolizations of discounted views (ibid).

\section{Everyday activism}

Pickerill and Chatterton (2010) argue that anti-, despite and post-capitalisms can be made in a 'revolution of the everyday', rather than a far-off utopia. As described above, postcapitalism is not an end-point, but a dynamic constant process. Chatterton and Pickerill (2010) state: 
Activists accept that their everyday lives will weave together practices and values that will sometimes feel embedded or trapped in capitalist ways of doing things, and at other times will be more liberatory or antagonistic. But they continue to move, acknowledging that autonomous political organising is always going to be contradictory, interstitial and in the making. (ibid: 488)

A rejection of wage labour; community building and creation of non-hierarchical structures are all applications of the creation of alternative futures in the everyday (Pickerill and Chatterton, 2010).

For Pickerill and Chatterton (2010) these everyday practices give meaning to postcapitalism and contribute to the creation of alternative futures in the present. From an analysis of case studies Pickerill and Chatterton (ibid) suggest that everyday activist practices are often of higher consequence to resistance than direct action techniques.

\section{Global Justice Networks}

Porta and Tarrow (2005) maintain that the global justice movement is a reaction to multiple forms of globalised networking such as free trade agreements and increasingly globalised markets. The global justice movement is often described as 'transnational' activism due to coordinated international campaigns, solidarity actions and solidarity campaigns (Porta and Tarrow, 2005). Transnational activism has had far-reaching effects since the beginning of the 1990's (Tarrow, 2005).

In contrast, Routledge, Cumbers and Nativel (2007) reject the concept of a transnational movement, instead positing a:

[...] series of overlapping, interacting and differentially placed and resourced networks (Routledge, Cumbers and Nativel, 2007: 2575) 
They call this series of networks 'global justice networks' (GJNs), a term that implies the social, economic, and environmental justice focus of the networks and movements (ibid). Routledge, Cumbers and Nativel suggest that reconceptualising a transnational movement as a global justice network implies difference and decentralisation rather than universalism and centralisation. Thus, the logic of affinity inherent in the organisation and networking of autonomous political groups is acknowledged.

GJNs are not concrete entities; rather they are adaptive and evolving processes. Campaigns, processes and methods of networking are constantly reformed and adapted through discussion and dissensus (Routledge, Cumbers and Nativel, 2007). The mutual solidarity created by GJNs allows inter-local connections and the valuing of both difference and similarities (Routledge, Cumbers and Nativel, 2007).

GJNs have received criticism. Tarrow (2005) questions the durability of transnational coalitions and warns of rifts between community activists and transnational focused activists. Klein (2004) has described this incompatibility as 'two activist solitudes' suggesting that transnational and locally focused activists must be mutually exclusive.

Routledge, Cumbers and Nativel (2007) voice serious concerns concerning the implications of the conflicting aims and strategies considered inherent within a GJN. They query whether a network can lead to successful social transformation (ibid). In contrast, Day's (2004) 'logic of affinity' offers an explanation of the political logic driving autonomous political groups.

\section{The logic of affinity}

Building on autonomous Marxist academics Hardt and Negri's (2000) theory of constituent power, political philosopher Day (2004) proposes a political logic: the 'logic of affinity' to better understand the "possibilities of non-hegemonic forms of social change" (Day, 2004: 717). 
This logic of affinity describes "that which always already undermines hegemony" (Day, 2004: 717) and is a reaction to the 'hegemony of hegemonies'. Day (ibid) believes that this 'hegemony of hegemonies' is implicit in the majority of academic perspectives concerning the 'movement of movements'. Day (ibid) describes the following conditions of the logic of affinity:

[...] a desire to create alternatives to state and corporate forms of social organisation, working 'alongside' the existing institutions; proceeding in this via disengagement and reconstruction rather than by reform or revolution; with the end of creating not a new knowable totality (counter-hegemony), but of enabling experiments and the emergence of new forms of subjectivity; and finally, focusing on relations between these subjects, in the name of inventions new forms of community (Day, ibid: 740).

In creating alternatives to state power, these groups are creating alternative futures in the present. Groups that employ the logic of affinity must aim to enable new forms of organization and community through non-hegemonic processes.

Day (2004) acknowledges the anarchistic basis of the logic of affinity in autonomous geographies, describing how anarchist theory has historically valued social revolutions constructed by affinities rather than revolutions based on replacing hegemonic power structures.

The logic of affinity is apparent in both direct action techniques and direct democracy processes.

\section{Direct democracy processes}

Grosz's (1999) quote at the beginning of this chapter describes the commitment of the global justice movement and global climate movement to a politics of autonomy and decentralization, of which direct democracy processes are highly valued (Chatterton and Pickerill, 2010). The use of direct democracy processes highlights what Franks (2003) 
describes as a 'means contributing to the ends' approach, which is in direct opposition to traditional Marxist-Leninist views that the ends justify the means.

Direct democracy processes used by the majority of activist groups involved in the global justice movement and global climate movement are based on anarchistic principles that value networks and social relationships. Direct democracy processes ensure constant renegotiations of politics (eg: Sen, 2010); even core goals may be changed as participants leave and new participants join (Chatterton and Pickerill, 2010). These processes employ the logic of affinity and cannot be truly understood from an academic perspective that does not acknowledge autonomy and networks:

$[\ldots]$ if anarchist influenced groups look disorganized, this is perhaps because the ways in which they are organized cannot be understood from within the common sense maintained by the hegemony of hegemony. Perhaps a new, uncommon sense is needed (Day, 2004: 741).

The application of direct democracy processes is a form of everyday resistance, as these processes directly confront the conventional politics of the majority (Chester and Welsh, 2008). As Doherty, Plows, and Wall (2007) state when describing environmental direct activists:

Their protests are challenges to the norms underlying political and capitalist institutions rather than calculated attempts to influence government. (ibid: 805)

While many collectives employ workshops and formal training to implement direct democracy processes, Chatterton and Pickerill (2010) critique the minimal amount of time spent discussing why consensus is used in preference to more conventional organizational processes. Chatterton and Pickerill (ibid) found that these hidden assumptions were often not discussed or addressed and that problems such as informal hierarchies and meeting fatigue were invariably not dealt with effectively. Interviewed research participants described frustration resulting from the lengths of time needed to 
come to consensus and perceived boundaries to action. However, Chatterton and Pickerill (ibid) considered the contribution of consensus to just and inclusive decisions as a significant benefit overall.

\section{Direct action}

As described earlier (Chapter Two), direct action is a protest action aiming to directly address an issue, rather than addressing it through lobbying or means that rely on existing governance structures (De Cleyre, 1912). Jordan (1998) describes direct action as:

[...]praxis, catharsis, and image rolled into one ... To engage in direct action you have to feel enough passion to put your values into practice: it is literally embodying your feelings, performing your politics (ibid: 133)

Thus, direct action in autonomous political groups appears as the physical manifestation of Day's (2004) logic of affinity. Direct action expresses a politics that aims to create alternative visions of the future in the present. For example, Doherty, Plows and Wall (2007) describe environmental direct actionists as having longer-term goals:

[...] rather than calculated attempts to influence state policy, EDA [Environmental Direct Action] is based on the aim of developing a resistance culture (ibid: 822).

In autonomous political groups, direct actions are organised by the use of direct democracy processes: in autonomous 'affinity groups'. In mass actions, horizontal groups "reproduce a horizontal networking logic on the tactical plane" (Juris, 2008: 63), stimulating a smaller scale version of a GJN.

The direct effects of a direct action event are considered subservient to indirect effects. Anderson (2004) suggests that the most significant effect of environmental direct action is claiming spaces of alternative cultural value. In an analysis of direct action in environmental activism Hamed (2008) found that research participants considered the 
indirect effects of direct action were the most powerful in empowering further activism and increasing mobilization.

Major indirect effects of direct action includes emotional and community impacts, which will be discussed later in this chapter.

Anderson (2004) acknowledges the role of direct action in claiming power, particularly in physically located manifestations, such as activist camps. Anderson (ibid) maintains that claiming these spaces is a direct challenge to claim political power. In claiming a politicised space, activists are also attracting visitors and supporters and thus encouraging the politicisation of others (ibid).

\section{Activist politicization}

Authors (Hetherington, 1998; Juris, 2008; Anderson, 2004) have highlighted the role of a physical site of direct action in transforming identities. Klein (2002) describes her attendance of a counter-summit thus:

These protests... are like stepping into a parallel universe. Overnight, the site is transformed...[...] the prospect of a radical change in political course does not seem like an odd and anachronistic idea but the most logical thought in the world (ibid: xxiv).

Anderson (2004) simply describes this transformation as: "people become activists" (ibid: 51.) Anderson maintains that physically locating activism allows people to experiment and form new identities by offering a politicised space (see Jackson and Penrose, 1993) of new social norms and few barriers (Anderson, 2004).

Chatterton and Pickerill (2010) state that the process of activist-becoming-activist is messy and complicated. Gibson-Graham (2006) argue that activists engage new practices of the self (ibid) and state that we need fugitive energies to free people from established identities and ways of acting. Through the process of politicization opportunities for new 
relationships and new identities are found and created (Gibson-Graham, 2006).

Social movement theorists Maddison and Scalmer (2006) maintain that activist politicization is the result of two events: activism resulting from a childhood experience or; activist involvement as a 'rebirth' which transformed or explained activists' adult lives. The activists that Maddison and Scalmer (ibid) interviewed believe that political involvement is central to their lives. They vocalized feelings that they had 'no choice' in their continued involvement; commitment was unfaltering. Maddison and Scalmer (ibid) hypothesized that their 'activist identities' protected their interviewees in times of failure.

\section{Community}

Juris (2008) highlights the transformative role of emotion in protest. He describes how intense and diverse emotions such as rage, anger, excitement and joy are often stimulated by involvement in activism. He has termed the contribution of these emotions to collective solidarity 'affective solidarity' (ibid).

Affective solidarity is particularly significant for autonomous collectives that utilise the logic of affinity (Juris, 2008), as these collectives rely on direct democracy processes and bonds of friendship (Polletta, 2002). Mass actions such as counter-summits are a powerful method of creating affective solidarity in making struggles visible and achieving catharsis (Juris, 2008).

Similarly, hooks (2004) discusses the importance of community sustenance and support mechanisms, building a community of support for radical and opposing identities and action. Community can provide stability in transitional and difficult times (Pickerill and Chatterton, 2006) but it is often in periods of relative inaction that communities and identities are formed and protected (Tarrow, 1998; Melucci; 1996). These 'submerged networks" are in themselves a "symbolic challenge to the dominant codes" (Melucci 1989: 60) and can provide time to translate their ideas into action (Pickerill and Chatterton, 2006). They may also create sustained and resilient communities instead of creating a cycle of reacting to crises (Pickerill and Chatterton, 2006). 
In a study of British direct actionists Doherty, Plows and Wall, (2007) hypothesised that close bonds of friendship in activist groups restricted recruitment and inter-group connections. They suggest that strong intra-group bonds of trust and friendship led to little effort being applied to recruitment. Doherty, Plows and Wall, (ibid) were highly critical of this characteristic, which they maintain leads to ineffective transmission of mobilisation and mutually exclusive cycles of protest.

\section{Emotions}

As the 'glue of solidarity' (Collins, 1990) emotions are integrally linked with community (Pulido, 2003). Social movement scholar James (1997) observed that mutual loyalties and shared emotions shape almost every aspect of a movement. He elaborates:

The collective emotions of protest are crucial for sustaining any movement. If emotion is the 'glue of solidarity', then movements depend on an emotional infrastructure (James, 1997:207).

Brown and Pickerill (2009) argue that activism is sustained by emotional reflexivity, and that spaces must be created for this purpose. They posit that activists must understand the links between "emotions and prefiguring social transformation" (ibid: 33) and imagine how it would feel to live in a post-capitalist society.

Juris (2008) implies that emotional bonds are particularly significant for autonomous political groups that have dynamic and adaptive political structures, as informal networks need high levels of commitment.

Yang (2000) has placed importance on the creation of "self-validating emotional experiences and expressions through active and creative pursuits" (ibid: 596). 'Emotional achievements' (ibid) such as joy and connection assist in developing affective solidarity (Juris, 2008). The stimulation of intense emotions, such as terror and bliss, results in high levels of affective solidarity and thus commitment and mobilization (Juris, 2008). 
Emotional infrastructure is created and sustained through shared spaces, communal processes and everyday tasks. Chatterton (2008) states that social centres allow physically grounded emotional connections through the "less visible but essential political work" (ibid: 7) of everyday practices such as direct communication.

James (1997) maintains that moral evaluations and emotional responses motivate political action. He compares protest to a religious ritual: describing how protest allows activists to communally voice moral concerns.

Building emotional connections and relationships is a political process (Flesher Fominaya, 2007). Pulido (2003) calls this process an 'inner life of politics'. Thus, emotions and emotional connections not only sustain activism, but are also forms of everyday activism in themselves: challenging and opposing a consumerist and individualistic society.

\section{Summary}

This chapter presents a literature review aiming to ground this research within relevant discourses. Firstly, I present a contextual base for reviewing autonomous geographies by outlining geographical discourses concerning activism and politics. This context aims to place autonomous geographies within a discussion of the place of activism and dissent within society. The definition and history of autonomous geographies is presented, with an acknowledgement of the location of this research within these discourses. Areas of particular interest in this research are laid out: alternative futures; everyday activism; global justice networks; the logic of affinity; direct democracy processes; direct action; activist politicisation; community and; emotions.

Various definitions of activism are explored and the place of dissent within democracy is examined. Swyngedouw (2008) argues that political activism must radically challenge societal processes, rather than simply offering resistance to them. Climate change is commonly framed as depoliticized and environmental organizations usually exhibit depoliticized tactics. Autonomous geographies were developed to respond to academic 
misunderstanding of autonomous political groups. There has been no application of autonomous geographies within Aotearoa, and this research aims to fill this niche.

The creation of alternative futures in the present is considered necessary for healthy democracy. These are messy and complicated and entail activists living between worlds: the real and the hoped for. Spaces of the political must be reclaimed to allow the creation of alternative futures. These alternative futures can be created in a revolution of the everyday through ordinary practices of resistance.

Global Justice Networks are adaptive and evolving processes which display the logic of affinity. The logic of affinity describes the anarchistic non-hegemonic possibilities inherent in autonomous political collectives.

Direct democracy processes and direct action are built on a political logic of affinity. Direct democracy processes are a form of everyday resistance and ensure a constant renegotiation of politics. Problems with direct democracy processes include time required and hidden assumptions. Direct action tactics are a physical manifestation of Day's (2004) logic of affinity. The indirect effects of a direct action event are often considered to be of more significance than the direct effects.

A physical site of activism is considered an important aspect in transforming identities. Activist politicization is messy and complicated. Social movement theorists suggest politicization stems from childhood experience or an activist 'rebirth' in adulthood.

Emotion and community are highly significant and fundamentally connected factors driving activism. Intense emotions stimulated during protest create powerful 'affective solidarities'. These are particularly important within autonomous political collectives that exhibit decentralized organizational structures. Community is of great value to activists and can provide sustenance in difficult and inactive times. Collective identities, activist culture and friendship are also of significance. However, it is suggested that bonds of strong friendship may negatively impact activist recruitment. Emotions are the 'glue of 
solidarity' and are similarly of specific significance to autonomous political collectives.

Emotions contribute to everyday activism and political processes, and emotional reflexivity is necessary for sustaining activism. 


\section{Chapter Five}

\section{Data Presentation}

This space of radical openness is a margin or a profound edge. Locating yourself there is difficult yet necessary. It is not a 'safe' place. One is always at risk. One needs a community of resistance (hooks, 1990: 149).

\section{Introduction}

This chapter presents information gathered from interviews with activists involved in Climate Camp Aotearoa for six months or longer at the time of primary data collection. Interviews focused on research participants' motivations, perceived differences between Climate Camp Aotearoa and other climate-focused groups in Aotearoa, and the alternative visions of the future activists considered themselves to be working towards. Through discussing these subjects I have explored the contribution of Climate Camp Aotearoa to the politics of climate change in Aotearoa and fulfill the research objectives of: exploring motivating factors that encourage climate activist's involvement; examining key differentiating factors; and exploring the contribution of Climate Camp Aotearoa to the creation of alternative futures in the present.

\section{Key interview themes}

The data collected was coded and a number of interview themes emerged. This chapter presents the eight interlinked and overlapping key themes that arose from coding. As research participants indicated no order of priority, themes have not been hierarchically ordered. I have attempted to include a diversity of views within themes while concurrently focusing on common concerns and considerations. In an effort to limit the misrepresentation of research participants quotes are included with as much context as possible and italics have been used to indicate emphasized words or phrases in research participant's speech. The eight themes are outlined below: 
The 'bigger picture' - A significant driver of research participants' involvement in Climate Camp Aotearoa was the utilization of a climate justice analysis towards climate change, including: recognizing the interconnectedness of climate change, considering climate change a social justice issue, emphasizing global links and encouraging a diversity of approaches tackling climate change. Recognizing the interconnectedness of climate change included recognizing the relationship between personal abuse and climate change.

Community - Community was considered a significant personal benefit from involvement in Climate Camp Aotearoa. Physical Climate Camps were suggested to be opportunities for experiencing healthy communities. Positive outcomes included support for activists, the difficulty of achieving goals in isolation, trust, and friendship. Two research participants suggested there is an overconcentration on internal community instead of outreach to external communities.

Hope - Research participants experienced hope resulting from their involvement in Climate Camp Aotearoa. Encouraging positivity was considered a significant benefit for activists working on the potentially depressing issue of climate change. Benefits of creativity, freedom and empowerment were also discussed. One participant suggested the collective allowed people to collectively voice, explore and experience their personal politics.

Direct democracy processes - The utilization of direct democracy organizational processes was considered a key difference between Climate Camp Aotearoa and other climate-focused groups in Aotearoa. Although not without criticism, research participants indicated that these processes encouraged political empowerment.

Direct action - The use of direct action in Climate Camp Aotearoa was commented on by many research participants. It was suggested that Governments could not be relied upon to create necessary changes and therefore direct action was a necessity. Participants 
proposed that the use of direct action within Climate Camp Aotearoa encourages politicization and empowerment.

Politicization - Research participants suggested that politicization was encouraged in Climate Camp Aotearoa by the utilization of direct democracy processes. Many participants described politicization resulting from involvement. Two participants suggested that this politicization may not reach outside the confines of the collective.

Alternative visions - A selection of research participants suggested that physical Climate Camps were spaces to experiment and trial alternatives ways of living. Climate Camp Aotearoa was described as allowing people to live out these alternative visions of society.

\section{The 'bigger picture'}

Research participants discussed how the collective has a broader analysis or 'bigger picture' perspective of climate change than other climate-focused groups in Aotearoa New Zealand. The predominant view was that climate change is an interconnected rather than isolated issue. Interviewee E (2010, pers. comm.) suggested that this 'bigger picture' analysis stems from links between Climate Camp and the anti-globalisation 'movement of movements' and differs significantly from the perspectives of past environmental groups:

I would like to think, anyway, that Climate Camp [has incorporated] what has come from the anti-globalisation movement, or what is now maybe anti-capitalist, or an analysis of the world economic system and of class and justice and stuff like that. I think that environmentalism is still the bigger slice of the pie, but that other side has come in, and that's why we're different from other environmentalist groups.

Similarly, Interviewee O (2010, pers. comm.) indicated: 
[Climate Camp Aotearoa is different] because it also has that social justice issue angle. It's unique, I think. There's other environmental groups who work on climate change, but the social justice issue is just kind of tokenistic. Like, I don't actually see them doing anything. [Other groups will] do things on their own terms but won't actually engage with those people or those groups that should be able to say how they want things.

Interviewee E (2010, pers. comm.) suggested that 'a bigger picture' analysis allows Climate Camp Aotearoa to experience freedom:

I really think Climate Camp's in a position to really push a lot of boundaries that other groups can't. We do come from a perspective that has got that analysis from other areas. Even racial analysis - that's not the right term - but we've been doing a lot of work on indigenous peoples and Tino Rangatiratanga and how that might fit in.

Research participants indicated that looking at 'the bigger picture' of climate change meant addressing abuse of power in everyday situations. Interviewee G (2010, pers. comm.) explained how this interconnected approach was implemented at the 2009 physical Climate Camp in Lower Hutt, when a historical issue concerning alleged abuse by one of the camp organizers was brought up:

When issues arose at the actual camp, we actually tried to deal with them, where as lots of groups I think would be like "well, that's completely unrelated to climate change, and that's why we're here, so that can be dealt with outside of the camp". Whereas, that's an actual real issue with society and without addressing that we're not going to address... we're not actually being who we want to be. So we need to take everything and address it how we think it needs to be addressed.

Some participants went further than discussing climate change as an interconnected or social justice issue: they indicated that they considered a focus on climate change as a 
means to creating social change. Interviewee K (2010, pers. comm.) described her perspective on Climate Camp Aotearoa:

We say 'climate change' and that's a really nice word to catch people in, but for me it addresses the root causes of why we're destroying our planet. So for me, the Climate Camp thing is not necessarily just about climate; it's not what I'm passionate about. I'm passionate about having a planet that is not being destroyed for profit.

For many research participants, the importance of interconnectivity included an awareness of global links and commonalities. Interviewee D (2010, pers. comm.) considered groups like Climate Camp Aotearoa as having the potential to link struggles between industrialized and non-industrialized nations.

I'd love to see Climate Camps [continue to develop] in more Western countries. 'Cause I think there's a lot of community action and a lot of understanding where people are suffering the most, but it's us, who have relatively comfortable lives, that are actually contributing to other people's suffering. So I'd really like to see Climate Camp empower people, and people coming together and stopping fossil fuel companies, and making a big impact in a way that internationally people can come together on as well.

Some research participants emphasized the need for diversity within interconnectivity. For example, Interviewee L (2010, pers. comm.) was concerned that current functioning of Climate Camp Aotearoa may be eliminating rather than fostering diversity:

I think there's a danger that if we go about doing projects like the World Dairy Summit, we're not just doing stuff like skill-sharing, we're homogenizing the movement, and we're kind of taking out that diversity. [...] I think sometimes there can be a bit of a fine line between that skill-share/networking and building a movement, and then there's the homogenizing a movement: everyone just getting 
on the same track and jumping on the same bandwagon and not going out on different directions.

\section{Community}

When discussing the personal benefits of being active in Climate Camp Aotearoa, research participants consistently indicated that community was significant. Interviewee J (2010, pers. comm.) described the sense of community she experienced through participating in Climate Camp Aotearoa:

It is quite a nice sense of community with Climate Camp. I do enjoy seeing everyone: catch ups, hearing about what's happening in other people's lives besides just [activism.] And when we have our national get-togethers it's good, it is a bit like a community reunion and stuff. 'Cause when there's only a few people doing stuff you really value those people that are doing stuff.

Interviewee D (2010, pers. comm.) suggested that a physical Climate Camp is an opportunity for people who don't have communities to experience being involved in one first hand:

I guess [Climate Camp]'s a place - from what I saw - for people that don't have their own marae, that don't have their own roots, to come together and feel part of a community, to see a community in action. Because a lot of people that came, maybe hadn't had the experience of having a marae, that they can go to and see how that other side works.

Friendship was also considered a personal benefit of being involved in Climate Camp Aotearoa. Interviewee E (2010, pers. comm.) indicated she has built friendships with many people active in Climate Camp Aotearoa:

I really get enjoyment out of working with people that are of a similar mind-set and have got really similar ways of organizing. I find that I'm really good friends 
with a lot of people involved in Climate Camp, which could be another whole discussion. That can be a bad thing as well - well not a bad thing, but it has its own issues and can be problematic.

While all research participants acknowledged the importance of community, Interviewee L (2010, pers. comm.) suggested that the focus on a Climate Camp community has negatively affected the capacity for Climate Camp Aotearoa to create change:

I think there's a real danger that activists spend all their time organizing Climate Camp and not actually doing any other campaigning. And what we need to be doing is going back to our communities and campaigning against new oil prospecting, campaigning against the expansion of the dairy industry, campaigning for better renewable energy and home insulation; campaigning for all those things and actually doing the hard yards; actually doing that really hard work.

Likewise, Interviewee M (2010, pers. comm.) suggested that activists should focus more on their local communities, rather than building a Climate Camp Aotearoa community:

It'd be nice to just see some other campaigning happening. People that can engage a bit more with people in local areas, you know? And Climate Camp people take that radical perspective and those skills and everything that we get from hanging out together and learning together, and then taking them and spreading them in their local communities.

\section{Hope}

Research participants stated that they experienced hope resulting from their involvement in Climate Camp Aotearoa. Interviewee G (2010, pers. comm.) described the necessity of positivity for people working on potentially depressing issues: 
I really see the importance of inspiring yourself and giving yourself hope when you think about the ways the world is. Often you feel like you're fighting constantly, and it can put quite a downer on things. Sometimes it feels like you're against things all the time and no one really likes to be negative all the time, it's so unhealthy. And then you go along to something like Climate Camp, and it's a really positive thing and it gives you hope, and it makes you happy and you have lots of fun and those things are really important for individuals as well. We need them to stay sane and to not burn out and to be people!

Interviewee K (2010, pers. comm.) suggested that Climate Camp Aotearoa had given her hope in the face of seemingly hopeless global issues. She specifically focused on the creative opportunities of being involved in the collective:

To be cheesy, it's probably given me hope when I was starting to feel quite over it, and like "I'm just going to focus on my own life and the world's going to pot and whatever". It gave me like "Oh well, I'd rather go down with this ship, singing, and chanting, and shaking pom-poms!" Or being creative... It's the amount of creativity, which is a really new way of approaching it.

Interviewee E (2010, pers. comm.) commented how Climate Camp Aotearoa inspired her:

Well, even though I have had highs and lows with Climate Camp, and at times it has been really frustrating... I've seen the harder parts of being involved with the group, But I still really, really love it, and it's still one of the main things that really drives me, and I'm constantly excited and inspired and it is a really important part of my life and who I identify with.

An analysis of activism as moral expression was articulated by Interviewee $\mathrm{H}$ (2010, pers. comm.). For him, Climate Camp Aotearoa is a collective that allows people to collectively express, explore and experience their personal politics, values and beliefs: 
If you kinda come to a realization that the world is pretty fucked up, and I think a lot of people do, and then you, in your own head, try to work out different ideas, try to analyze why it is like that, and dig more and more. So you come up with ideas and you come up with other ways of thinking and ways how this world could look better.

You develop a personal politics, personal attitudes, towards it, and then, if you've got them, I think that you don't do anything about it, or you can't do anything about it, it can be very uninspiring. So I think Climate Camp, for me, was one of those platforms where you can practice your personal politics, you can put in a real situation your values and beliefs.

\section{Direct democracy processes}

A number of interviewees have been involved in a variety of environmental and/or climate groups. Many discussed the differences between the processes used by Climate Camp Aotearoa and other climate-focused groups in Aotearoa New Zealand. Interviewee K (2010, pers. comm.) described non-hierarchical processes as being the primary differentiator:

I definitely think [Climate Camp Aotearoa's] got a unique place within the climate movement. In terms of the fact that it's grassroots - I kinda hate that term - but it's participant-led. It has much stronger anarchist principles without being an anarchist group per say. It definitely follows through more collective decisionmaking processes. It's a non-hierarchical model and that's really obvious.

Interviewee O (2010, pers. comm.) suggested that high levels of participation and empowerment are not achievable in hierarchical organizations such as Forest and Bird:

Part of Climate Camp - as I'm sure you know - is empowering ourselves to make decisions and taken action ourselves. So we have to learn how to do that, and 
that's not going to happen in a group that's 'top down' like the ECO Network or Forest and Bird.

Many research participants indicated that empowerment resulted from the utilization of Climate Camp Aotearoa processes. Interviewee J (2010, pers. comm.) described the empowerment she experienced after the 2009 camp in Lower Hutt:

When we had our first Climate Camp that was like so empowering! Being in a group where you don't really have much say in the way its run... [is not empowering.] When we had our first Climate Camp and we had our neighbourhood meetings and stuff... the whole way it was run was a total buzz for me. And the way we planned our action; the whole affinity group thing.

Likewise Interviewee C (2010, pers. comm.) explained how a physical Climate Camp is an empowering space:

That's the most exciting thing, I think: just empowering people to take charge of their own lives for themselves. The Camp is only a physical place for this thing to happen; a small area where, for a short amount of time, people can choose to live their lives in a different way than they have to for the rest of the year in capitalist society.

Interviewee E (2010, pers. comm.) believed that consensus decision-making and nonhierarchical processes ensure participants are valued and active:

It's just an acknowledgment of the fact that "yeah, you are just as important as anyone else and you do have a voice if you want it" and "you will be consulted about every decision, and given the opportunity to state your opinion" is something really important to do, and will make people feel that - if and when they want to - that they're totally welcome to jump in on there. 
Striving for communities that experience minimal abuse and domination was considered by some research participants to be a primary goal of using direct democracy processes. For Interviewee G (2010, pers. comm.) these processes are more effective, more sustainable and more equitable than hierarchical processes:

To me, its people who are going to make the changes, and if people aren't feeling - I don't know, how can I explain - I guess a way that's there's no sort of domination, or trying to reduce hierarchies and domination and all that. I mean, nothing's perfect, but the Climate Camp way of organizing and structure and all that is at least trying to reach some sort of different ways of doing things, that is seen as a fairer, better way of doing things, and way more sustainable in terms of people.

Interviewee E (2010, pers. comm.) offered a critical analysis of problems she sees with current processes, mainly time, energy and frustration:

At Climate Camp New Zealand it's kinda big on these processes and the systems that we go through, and putting it really, really clearly, and trying a lot to fit into these systems that we've created, because they're quite cool, the concept. And then I think a lot of energy is lost, or a lot of frustration is created 'cause we're continuously going "how does this fit into our process?!"

\section{Direct action}

Many research participants commented on the direct action focus within Climate Camp Aotearoa as a differentiating factor. A number of research participants suggested that direct action was necessary as governments could not be relied upon create real societal change. For example, Interviewee J (2010, pers. comm.) commented on the political necessity of direct action:

It feels good to know I'm doing something about [climate change]. And 'specially with a group of like-minded people who have that same - you know - realize 
there's no way the government's going to... not relying on the government, or governments to do anything. [Instead Climate Camp Aotearoa participants are] doing direct action and looking at the root causes of climate change.

Some research participants discussed how Climate Camp encourages politicization and empowers people through using direct action. Interviewee G (2010, pers. comm.) commented on her own experiences:

In terms of empowering and direct action I think people have a fear of the unknown, and most people don't challenge certain powers, and I guess Climate Camp is challenging so many things that you never think of challenging often - or I would never have thought of challenging by myself. And then, when you're with a group of people and you feel empowered to things... And once you do something you feel that actually, pretty much anything is possible and things aren't that scary and maybe it's okay?

Similarly, Interviewee H (2010, pers. comm.) suggested that Climate Camp creates a 'platform' for people to become politicized and active through encouraging direct action:

[Direct action is] another inspiring thing of what Climate Camp gives to me. People can actually go and do things; it gives you this platform to start from. And I think it's inspiring for people who come, who get involved and they're from a bit of a different background or different perspective, and all of a sudden they see this Climate Camp thing as being a really attractive thing. From not being sure, they go and participate in direct action and they start doing things, like challenging the oppressive machine by just putting themselves in direct confrontation with it.

Interviewee C (2010, pers. comm.) indicated that physical Climate Camps offer space and opportunities for radical activists to organize: 
[A camp] creates an opportunity for people to get together and do things - do actions or whatever - on whatever scale they're comfortable with. It creates opportunities for more radical or hard out militant - whatever you wanna call it to be organized and to happen. 'Cause you've got this broad base of support for environmental stuff and lots of people who are probably more into intense stuff, meeting up and deciding they want to do something together.

\section{Politicization}

A number of research participants suggested that utilizing direct democracy processes encourages activist politicization. For instance, Interviewee C (2010, pers. comm.) commented on the lack of political activity in Aotearoa and suggested that nonhierarchical processes may be part of the answer:

I think that getting people politically active is just a point of change in the culture we live in. In New Zealand it's quite a conservative viewpoint that most people have. So I think it is really is, if you get all these people together there's like a politicizing event for some people. They realize they can do these things and that they don't have to sit by and let other people make decisions for them.

Research participants often described their own politicization as resulting from experiences at a physical Climate Camp. Four research participants described their politicization as resulting from involvement in Climate Camp Aotearoa or international Climate Camps. Interviewee B (2010, pers. comm.) indicated that her politicization partially resulted from involvement in Climate Camp Aotearoa:

Activism is completely new to me - until I went to Climate Camp - other than just living my own life and my thoughts on being sustainable. It was having that awareness of our environment and health and food that was just a part of my life, I guess. I wasn't involved in any other movements and any other groups... I was just an individual with thoughts and feelings. [Climate Camp Aotearoa got me 
involved] as well as the influence of people around me. Climate Camp was certainly the first door that opened to experience it all.

Interviewee H (2010, pers. comm.) discussed how Climate Camps may politicize people who are interested in climate change:

Climate change is like kind of a 'hot topic' now: there's a lot of groups doing things about it; everyone talks about it from prime ministers to, like, miners. All the spectrum of society is talking about it. So, more and more people are interested and I think the role of Climate Camp is utilizing this big public debate and shifting it away into this more radical perspective.

Like making people who are more interested in climate change issues, making them interested in looking at capitalism and have this bit of radical perspective opened and brought to them in this amazing space [at a Climate Camp].

Both Interviewee D and Interviewee L spoke about observing the political empowerment of others at the 2009 Climate Camp in Lower Hutt. Interviewee L (2010, pers. comm.) observed politicization, but considered that politicized people may only be active in Climate Camp, rather than necessarily climate campaigning:

There were a lot of Greenpeace fundraisers that were at the camp, and they were really interested and engaged, and really motivated and onto it. And they were really keen and inspired people and spend their day collecting money for Greenpeace. But then to see them come to Camp, to learn about direct action and to be involved in the Day of Action, to meet other people who are campaigners in all sort of different ways, and to break down some of those walls. And some of them are now still involved in organizing Climate Camp, which is obviously heaps better than just turning up to Climate Camp [...] 
And that's' really cool to see people involved and engaged in these processes, but I think it'd be cool if these people would actually work to be involved in campaigns.

Both Interviewee $\mathrm{M}$ and Interviewee L indicated that that Climate Camp has not been entirely successful in politicizing people. They considered that politicization has led mostly to people becoming active in organizing Climate Camp Aotearoa, rather than politicizing people into becoming active on various climate campaigns. Interviewee $\mathrm{M}$ (2010, pers. comm.) described his feelings thus:

I think we need to recreate those sorts of events [such as the physical 2009 camp] that foster a coming together of diversity and diverse tactics and diverse groups, whilst retaining our core goals and principles and aims. But kind of reaching out and radicalizing, you know, some of those groups; bringing a different narrative or analysis to some of those groups, and skill-sharing and then going away again and putting it into action.

\section{Alternative visions}

A number of research participants directly state that Climate Camp, particularly physical

Climate Camps, could be spaces to experiment and try out new ways of living and society. Interviewee E (2010, pers. comm.) outlined this:

Basically, Climate Camp is like a little model, or a little experiment, I guess, where we're able to put some of these ideas in practice. And it kinda utilizes climate justice or climate change as its practical or theoretical topic or issue.

Interviewee I (2010, pers. comm.) agreed:

It's like we're taking action but we're also coming from a perspective of trying to make an ideal society. Like we're living the way we think people should be living, like the way it should be, as well as saving the planet. 
Interviewee E (2010, pers. comm.) suggested that Climate Camp was unique in that it was an attempt to live alternative visions now rather than the future:

What I like about Climate Camp, and what I also think sets it apart, is that the principles and ideas of our alternative visions are what we're trying to put in place now. We're not striving for it in the future; we're trying to do it in the here and now as well. I think it has the potential to give people a lot of hope, that actually you can live your life in a just and sustainable, and beautiful, meaningful way now, you don't have to fight-fight-fight and wait, and try... and eventually it might come? That can be really hard and discouraging.

Research participants suggested the processes Climate Camp Aotearoa uses allow the collective to implement alternative visions now rather than in the future. Interviewee $\mathrm{C}$ (2010, pers. comm.) voiced his opinion:

You can only really do what you can, and use your energy in the best way you think you can. Use your time in the most productive and most fulfilling way. You can't really pin your hopes on the future. You have to work on the things you can work on. That's why I think process is so important; it's a continual process of living the way you think things should turn out.

Interviewee $\mathrm{G}$ (2010, pers. comm.) agreed and elaborated:

To me it's that whole 'another way is possible'. It's an example of stepping out of the system that we have and using a new way of organizing that actually works and can leave everyone feeling actually really happy with the results. To me, I guess environmental issues and climate change and stuff was the original reason that I was drawn to Climate Camp. But it's so different now: I see it's way more than just anything to do with the environment: it's to do with the way we live; it's to do with the way everything is organized and the system that's in place; opening 
up other ways of doing things and being an amazing example of how successful that can be and how it can actually work.

Interviewee F (2010, pers. comm.) emphasized the role of diversity and opening up spaces for the creation of alternative visions:

We need to open up spaces for all these millions of ideas to actually happen in. It's a battle - in some ways - between diversity and uniformity. And we all know when it comes to the environment, that diversity is power in environmental systems. And I'm starting to sound like a hippy, but it's sort of like that with social movements too. 'Cause social movements that are really top-down and really centralized always get smashed. Ones that are diverse enough that you can't cut all their millions of heads off at the same time: they end up winning. 


\section{Chapter Six}

\section{Critical Discussion}

What if we were to accept that the goal of theory is not to extend knowledge by confirming what we already know, that the world is a place of domination and oppression? What if we asked theory instead to provide a space of freedom and possibility? (Gibson-Graham, 2008:7)

\section{Introduction}

This chapter is a discussion of the data collected from a literature review (Chapter Four) and thematically coded fieldwork data (Chapter Five) contextualised by the historical and political background of activism in Aotearoa (Chapter Two). This discussion is framed by the scholar activist epistemological lens described in the research methodology (Chapter Three) and builds a picture of the contribution of Climate Camp Aotearoa to the politics of climate change in Aotearoa, using autonomous geography discourses.

For ease of analysis, the thematically coded primary data is discussed within the context of each research objective. First, a discussion of the motivating factors that encourage research participant's involvement in Climate Camp Aotearoa is presented. Key factors that differentiate Climate Camp Aotearoa from other climate-focused groups and organizations in Aotearoa are discussed. The contribution of Climate Camp Aotearoa to the creation of alternative futures in the present is then set out.

Research Objective One: To explore motivating factors encouraging climate activists' involvement in Climate Camp Aotearoa.

Research participants indicated three themes as primary motivating factors in their involvement in Climate Camp Aotearoa: the 'bigger picture', community and hope. 


\section{The 'bigger picture'}

The 'bigger picture' focus of Climate Camp Aotearoa was a key motivating factor for research participant's involvement. Interviewees discussed aspects of this broader analysis such as the interconnectedness of climate change and an emphasis on global links and diversity.

I consider this 'bigger picture' focus as an application of a climate justice perspective that views climate change as a symptom of a neoliberal, corporate-based, globalized economy. As described in the introductory chapter of this thesis (Chapter One), the global climate justice movement emerged out of the climate justice movement that began in the 1990's.

As a collective that considers itself part of the global climate justice movement, Climate Camp Aotearoa is an autonomous group linked internationally and nationally with other autonomous groups. Climate Camp Aotearoa therefore contributes to a Global Justice Network (GJN) (Routledge, Cumbers and Nativel, 2007) within a series of connected and overlapping networks working towards social, economic, and environmental justice (ibid). I suggest that the mutual solidarity established by being part of a GJN has given research participants a better understanding of the international context of local issues and contributed to positive emotions concerning global connections.

Three research participants indicated that Climate Camp Aotearoa's concentration on climate change was simply a focus that enabled them to work towards wider social change. A climate justice perspective maintains that the root cause of climate change as corporate globalization (Global Justice Ecology, n.d.). From the perspective of the three research participants mentioned above, halting corporate globalisation will not only begin to tackle climate change, but also begin to tackle many other societal issues considered important by the research participants.

Day's (2004) logic of affinity offers a foundation for the 'bigger picture' motivation. Built on Hardt and Negri's (2000) theories of constituent power, Day's (2004) political 
logic is designed to better understand forms of social change that are non-hegemonic. This non-hegemonic political logic allows the networking and intra-collective processes of GJNs to be fully understood. Climate Camp Aotearoa exhibits the logic of affinity in that it desires to build alternatives to state and corporate led organisation; works 'alongside' rather than with state institutions; may employ disengagement and reconstruction; attempts to enable experiments and new subjectivities; and focuses on relationships and new forms of community (Day, 2004).

A number of research participants acknowledged the relationship between interpersonal power relations and climate change. This view connects climate justice to everyday issues of social justice. I consider this an application of everyday activism (Chatterton and Pickerill, 2010), as issues of abuse are dealt with on a daily level and are considered significant in creating everyday utopias. Encouraging non-violent behaviour is an extension of the creation of alternative futures in the everyday (Pickerill and Chatterton, 2010). This willingness to deal with issue of abuse is an everyday practice that gives meaning to post-capitalism (Chatterton and Pickerill, 2010). Pickerill and Chatterton (ibid) suggest that the accumulation of this sort of everyday practice is often of greater importance than direct actions in building alternative futures.

\section{Community}

The thematically coded data collected indicates that community was a significant driver of involvement in Climate Camp Aotearoa.

Emotion is the glue of solidarity (Collins, 1990), and movements depend on emotional bonds (James, 1997). Juris (2008) has created the term 'affective solidarity' to describe activist feelings of community driven by emotion. In Climate Camp Aotearoa, research participants' feelings of community will be sometimes driven by the intense emotions generated by communal protest. Juris (2008) suggests that affective solidarity is extremely significant for autonomous collectives driven by the logic of affinity. 
Climate Camp Aotearoa depends on direct democracy processes and connections of friendship and trust, and these informal organisational structures determine that emotional bonds must be a primary tie between individuals (ibid).

Doherty, Plows and Wall (2007) suggested that close friendships within activist groups restricted activist recruitment and inter-group connections. In this research process two research participants voiced similar views, suggesting that Climate Camp Aotearoa has an overconcentration on internal community that restricts connections with local communities. Doherty, Plows and Wall, (ibid) suggest that strong intra-group friendships and high levels of trust led to little time or effort in recruitment. While Doherty, Plows and Wall, (ibid) were critical of this pattern, I maintain that the importance of affective solidarity determines that these bonds of friendship and trust are essential for affective solidarity and therefore the functioning of an autonomous political group.

Research participant's valued the support for activists that Climate Camp Aotearoa provided, and spoke of the difficulty of achieving goals in isolation. hooks (2004) has articulated the significance of community sustenance and support mechanisms for activist groups. She describes how radical and oppositional identities and actions need support from a community of like-minded people (ibid). Climate Camp Aotearoa is offering this necessary support and community to activists, motivating them to continue participating in activist collectives.

Research participants experienced the importance of activist communities in times of inaction. Communities are necessary for sustainable and resilient activism and community building is a form of everyday activism, part of the dynamic continual process of creating alternative futures in the everyday (Pickerill and Chatterton, 2006). Melucci (1989) suggests that community is a political action in itself, in that it provides a "symbolic challenge to the dominant codes" (ibid: 60). 


\section{Hope}

Research participants expressed feelings of hope resulting from involvement in Climate Camp Aotearoa.

Emotions are powerfully linked with concepts of community (Pulido, 2003). The hope that research participants described is a 'glue of solidarity' (Collins, 1990) that ties activist groups together. According to Juris (2008) as an autonomous political collective that is organized by direct democracy processes, emotions will be a significant part of what sustains research participants' involvement in Climate Camp Aotearoa.

Intense positive emotions are examples of Yang's (2000) 'emotional achievements': the establishment of "self-validating emotional experiences and expression" (ibid: 596). These heightened emotions contribute to the creation of affective solidarity, a strong form of communal connection that sustains activists (Juris, 2008). Research participants maintained that positivity was a significant benefit for activists working on climate change. This positivity may have, in part, resulted from an awareness of community and affective solidarity.

James (1997) highlights the significance of moral evaluations and emotional responses in motivating political action. He suggests that protest is similar to a religious ritual in allowing people to collectively express moral concerns vocally and collectively. Interview $\mathrm{H}$ expressed similar views in describing Climate Camp Aotearoa is a collective that allows people to collectively explore and experience their personal politics, values and beliefs. Climate Camp Aotearoa can therefore be tentatively likened to a religious ritual.

The formation of emotional connections and therefore communities is a political process in itself (Fleshher-Fominaya, 2007). By stimulating intense emotions Climate Camp Aotearoa is contributing to the "hidden work of rebuilding social relationships around emotions, solidarity and trust" (Pickerill and Chatterton, 2006: 2). 


\section{Research Objective One: summary}

The 'bigger picture' of Climate Camp Aotearoa was a key motivational factor for research participant's involvement. The 'bigger picture' is a direct result of using a climate justice perspective that originated from the global justice movement. Research participants valued the GJN involvement of Climate Camp Aotearoa and acknowledged the attempt made at the 2009 physical Climate Camp to deal with an issue of personal abuse, a form of everyday activism.

Community was a significant driver for involvement in Climate Camp Aotearoa. Affective solidarity is a primary tie between individuals involved in Climate Camp Aotearoa. While research participants did criticise Climate Camp Aotearoa as having an overconcentration of internal community, the importance of affective solidarity from internal friendships and connections cannot be underestimated. Climate Camp Aotearoa provides necessary support and community to activists, thus allowing them to continue activist practices. Community building is a political action in itself: a form of everyday activism.

Hope was a key motivating factor in research participants' involvement in Climate Camp Aotearoa. Emotions are powerfully linked with community and are an important part of what sustains activist involvement in Climate Camp Aotearoa. Emotions are significant in forming affective solidarity. In allowing activist's to collectively voice their concerns, Climate Camp Aotearoa can be likened to a religious ritual. In stimulating heightened emotions Climate Camp Aotearoa is contributing to the politically charged 'hidden work' of rebuilding relationships.

Research Objective Two: To examine key factors differentiating Climate Camp Aotearoa from other climate-focused groups and organizations in Aotearoa.

Research participants indicated three key themes differentiating Climate Camp Aotearoa from the majority of climate-focused groups and organizations in Aotearoa. These were: 
the direct democracy processes, direct action and politicization. These themes are discussed within the following analysis of Climate Camp Aotearoa.

\section{Direct democracy processes}

The use of direct democracy processes is a key factor differentiating Climate Camp Aotearoa from the majority of climate-focused groups and organizations in Aotearoa.

Autonomy is power relationship (Chatterton, 2008) and the boundaries between autonomous and non-autonomous geographies are constantly reconstructed (Pickerill and Chatterton, 2006). In using direct democracy processes, Climate Camp Aotearoa is ensuring a constant political renegotiation (eg: Sen, 2010) where collective goals can change easily (Chatterton and Pickerill, 2010). Direct democracy processes allow collectives to function fluidly, encouraging the re-evaluation of collective goals as participants' involvement changes.

As an autonomous political collective, Climate Camp Aotearoa is committed to a politics of decentralization, which is exhibited in organizational processes utilized. Groups contributing to GJNs are autonomous and work together as a network, rather than a vertically organized single entity.

Climate Camp Aotearoa does not support the hegemonic "universalizing conception of social change" (Day, 2004: 76) accepted by Marxist and liberal activists. Instead, Climate Camp Aotearoa utilizes the logic of affinity, that is: radical social change that is not hegemonic (Day, 2004). This anarchistic logic is founded on a belief that, as Holloway (2002) states, transforming and claiming state power reproduces that power with new leaders.

Interview E (2010, Pers. Comm.) described the problems that she saw as resulting from Climate Camp Aotearoa's use of decentralized processes: largely time, energy and frustration. Given my prior involvement in Climate Camp Aotearoa, I suggest it is likely that the collective experiences similar problems to those highlighted by Chatterton and 
Pickerell (2010). Chatterton and Pickerill (2010) indicated that hidden assumptions concerning decentralized processes were often not addressed, expressed, or dealt with effectively. Similarly to Chatterton and Pickerill (ibid) I also suggest that the contribution of direct democracy processes to just and inclusive decision-making overrules these negative factors.

Climate Camp Aotearoa's utilization of direct democracy processes is a direct challenge to existing societal organisation, and therefore is a form of everyday resistance.

\section{Direct action}

Research participants indicated that direct action was a key factor differentiating Climate Camp Aotearoa from other climate-focused groups and organisations in Aotearoa.

Research participants voiced opinions that direct action was necessary, as governments could not be relied upon to create the change that are considered needed. This is an unsurprising result, given the direct democracy processes favoured by the collective and the climate justice movement's commitment to 'community-led solutions' (Global Justice Ecology, n.d.). Direct actions are organized in a decentralized manner, using 'affinity groups' which self-organize and network together when major decisions need to be made.

Direct action tactics demonstrated by groups such as Climate Camp Aotearoa are founded on Day's (2004) 'logic of affinity': the political logic of non-hegemonic social change. Just as direct democracy processes are a means of embodying autonomy, decentralisation and collective empowerment in decision-making, direct action is "literally embodying your feelings, performing your politics" (Jordan, 1998: 54).

In focusing on concerns other than influencing government, direct action carried out by Climate Camp Aotearoa differs significantly from the direct actions of non-politically autonomous environmental organisations such as Greenpeace Aotearoa. 
Following Hamed (2008) and Anderson (2004), the indirect effects of Climate Camp Aotearoa focus on direct action may be greater than the direct effect of any one given action. Anderson (ibid) suggests that direct action is of great importance in claiming space for alternative cultural values, while Hamed (ibid) maintains that new activist politicisation and empowerment may result from direct action activities.

I posit that the indirect effects of Climate Camp Aotearoa's direct actions are emotional connection and community. Thus, these indirect effects of direct action contribute to everyday activist practices.

\section{Politicization}

Research participants suggested that politicization was encouraged by Climate Camp Aotearoa, largely by the utilization of direct democracy processes. Some participants described politicization resulting from their own involvement in Climate Camp Aotearoa.

Anderson (2004), Hetherington (1998) and Juris (2008) suggest that physical spaces are deeply significant for activist politicisation. Anderson (ibid) suggests that the creation of a politicised physical space allows people to form new activist identities, while Klein (2002) describes these spaces as "stepping into a parallel universe" (ibid: xxiv). In creating a physical camp, Climate Camp Aotearoa created a physical politicised space of new social norms and few barriers (Anderson, 2004) where radical political transformation and new methods of organising society appear possible. In entering a physical camp, Climate Camp attendees may have developed Gibson-Graham's (2006) "new practices of the self", allowing politicization.

Through removing cultural norms, barriers to certain behaviours are removed (Doherty, Plows and Wall, 2007). In creating a physical Climate Camp, Climate Camp Aotearoa created a platform for articulation and outreach. As a 'homeplace' (hooks, 1990), a physical camp provides a safe space for politicization. 
Research participants' experiences at the physical camp or using empowering processes in meetings may have contributed to Maddison and Scalmer's (2006) theories of politicization as a transformative 'rebirth'.

A small number of research participants indicated that politicization does not reach outside the confines of the collective. As physical camps appear to be the greatest source of activist politicization and there only one physical camp in Aotearoa to date, it is likely that this has greatly restricted activist politicization.

\section{Research Objective Two: Summary}

The use of direct democracy processes differentiates Climate Camp Aotearoa from the majority of climate-focused groups and organizations in Aotearoa. This is a characteristic of autonomous political groups and groups within GJNs. Hidden assumptions concerning direct democracy processes may not be effectively dealt with within Climate Camp Aotearoa, but the inclusivity of these processes surpasses these issues. Climate Camp Aotearoa's utilization of direct democracy processes is a form of everyday resistance.

Direct action is a primary differentiator between Climate Camp Aotearoa and other climate-focused groups and organisations in Aotearoa. Politically autonomous groups such as Climate Camp Aotearoa display direct action tactics driven by Day's (2004) 'logic of affinity'. Direct action is a physical embodiment expression of politics. The direct actions carried out by Climate Camp Aotearoa differ significantly from direct actions carried out by groups such as Greenpeace, which aim to lobby politicians and reform. The indirect effects of direct action may outweigh the direct effects. Politicization and empowerment may be indirect effects of direct actions. These indirect effects are forms of everyday activism.

Politicization was encouraged by participation in Climate Camp Aotearoa. This differentiating factor was largely seen as originating from experiences at a physical Climate Camp. Politicised spaces provide space for the formation of new identities, as when cultural norms are removed, barriers to new behaviours are also removed. As a 
'homeplace' a physical Climate Camp provides a safe space for engaging with 'new practices of the self' and thus politicization. As physical camps are the primary catalysts for politicization, Climate Camp Aotearoa's capacity to politicize activists has been limited by the one camp that has been organized to date.

Research Objective Three: To explore the contribution of Climate Camp Aotearoa to the creation of alternative futures in the present.

As an autonomously political collective, Climate Camp Aotearoa is challenging societal processes by claiming space and using it to explore different methods of societal organization. From the perspective of Swyngedouw (2008), Climate Camp Aotearoa must be a genuinely political collective embracing diversity and opening up new methods of living in 'post-political' and 'post-democratic' societies.

In comparison to reformist climate-focused groups and organizations who seek incremental and reformist changes, Climate Camp Aotearoa calls for, and implements, radical ideas of transformation. While climate change is generally framed in a depoliticized manner that reproduces liberal-capitalist order, Climate Camp Aotearoa attempts to repoliticise the issue in aiming to transform the existing order. The creation of alternative futures is a key factor in addressing climate change (Swyngedouw, 2010).

Gibson-Graham (1996) argues that post-capitalist and capitalist politics are constantly being renegotiated. This implies post-capitalism is already part of the present, allowing for the creation of alternative futures in the present (Pickerill and Chatterton, 2006). It is these alternative visions that are necessary for healthy democracies.

While some research participants directly described Climate Camp Aotearoa as contributing to the creation of alternative futures, the remainder of research participants indirectly attributed the creation of alternative futures through everyday activism such as community building and direct democracy processes. Chatterton and Pickerill (2010) suggest that alternative visions are sustained through such everyday resistance. Vaneigem 
(1979) described acts such as these as forming a revolution of the everyday. Even working together collectively can be thought of as an act of everyday revolution, as it seeks to transform societal order. Chatterton and Pickerill (2010) suggest that everyday activist practices are of greater significance than resistance than confrontational direct action and thus give meaning to post-capitalist processes.

As discussed under Objective Two, empowering processes were an important part of Climate Camp Aotearoa. Using Chatterton and Pickerill's (2010) analysis, I consider the horizontal organizational structures, community-building and empowering processes as everyday activist practices which are likely contributing to the creation of 'anti-, despite and post capitalisms' (Chatterton and Pickerill, 2010): alternative futures in the present.

Research participants highlighted their desire to create and test these alternative futures now, rather than in some distant utopia. For instance, Interviewee G (2010, pers. comm.) described the 2009 physical Climate Camp as "an amazing example of how successful" living in a different society could be. I suggest that research participants in Climate Camp Aotearoa are living between capitalist and post-capitalist worlds: in messy, interstitial and contradictory spaces (Chatterton and Pickerill, 2010).

Swyngedouw (2008) argues that practices aiming to be both political and democratic require space to create symbolic geographies of their own: to experiment with radical forms of democracy and to voice marginalized views. In physically claiming a public space for a Climate Camp, Climate Camp Aotearoa may be claiming symbolic geographies. This reclamation of physical and political space is what Swyngedouw (2008) suggests is necessary to allow space for alternative visions of the future. He maintains that this space should be used to experiment with versions of radical democracies. Physical Climate Camp spaces are encouraging exactly that: they are offering space to experiment with direct democracy processes, community building and direct action.

\section{Research Objective Three: summary}

Climate Camp Aotearoa is challenging societal processes by claiming space and 
exploring alternative methods of organizing societies. Climate Camp Aotearoa is a genuinely political collective, calling from and implementing radical ideas of transformation. Thus, Climate Camp Aotearoa is contributing to a politicization of climate change, an issue that is commonly depoliticized.

Post-capitalist and capitalist politics are fluid processes, allowing for the creation of alternative futures in the present. These alternative visions are necessary for healthy democracies and allow hoped-for futures to be experimented with. Physical Climate Camps provide opportunities to live and test out these alternative visions, both overtly, and through everyday activist practices. I suggest that direct democracy processes, community building and direct action contribute to the creation of alternative futures in the present, thus contributing to anti-, despite and post capitalisms (Pickerill and Chatterton, 2010). Research participants are therefore living between real and hoped for worlds. Climate Camp Aotearoa is contributing to the creation of alternative visions, enacted in the present, thus contributing to practices of genuine politics. 


\section{Chapter Seven}

\section{Conclusion}

Democratic politics, therefore, are radically anti-utopian; they are not about fighting for a utopian future, but are precisely about bringing into being, spatialising, what is already promised by the very principle upon which the democratic political is constituted, ie: equality (Swyngedouw, 2008: 22).

\section{Introduction}

In this final chapter I revisit the main outcomes of the critical discussion (Chapter Six) and reflect on the following aspects of the research process:

- the efficacy of using a scholar activist epistemological framework: what worked and what did not;

- the contribution of this research to Climate Camp Aotearoa; specifically in regards to the creation of a non-academic research output; and

- $\quad$ areas for future research.

\section{Responding to the research questions}

Significant motivating factors encouraging climate activist's involvement in Climate Camp Aotearoa included the 'bigger picture' focus expressed by the collective: a climate justice perspective, interconnected within a Global Justice Network (GJN) which utilizes the logic of affinity. Climate Camp Aotearoa stimulates affective solidarity and provides important community support and sustenance to climate activists. Lastly, Climate Camp Aotearoa is a source of hope and allows activists to collectively voice their concerns.

The utilization of direct democracy processes and direct action tactics were key factors differentiating Climate Camp Aotearoa from other climate-focused groups and organizations in Aotearoa. Direct action tactics and direct democracy processes both contribute to everyday activist practices and express a non-hegemonic 'logic of affinity' found in autonomous political groups. Physical camps provide safe spaces for activist 
politicization, allowing camp attendees to form new identities. More climate camps should be organized if further activist politicization is desired by Climate Camp Aotearoa.

\section{Climate Camp Aotearoa contributes to the creation of alternative futures in the present} considered necessary for healthy democracies. Physical climate camps provide opportunities to live and test out these alternative visions, primarily through everyday activist practices such as the utilization of direct democracy processes and community building. Activists involved in Climate Camp Aotearoa are living between real and hoped for worlds, using identities and spaces which are concurrently anti-, despite, and postcapitalist. In claiming space and exploring alternative methods of societal organization Climate Camp Aotearoa is a genuinely political collective contributing to a repoliticization of climate change.

\section{Utilising a scholar activist epistemological framework}

I believe I made the correct decision to use a scholar activist epistemology as a framework for this research. As an embedded participant in Climate Camp Aotearoa, my role as both student academic and activist was fluid. The use of a scholar activist epistemological framework allowed me to blur these boundaries within the restrictions of writing a Master's thesis. In utilising a scholar activist epistemological framework I fused my personal politics with my academic research: I consider this to have greatly minimised potential problems which may have resulted from my dual involvement.

I have negotiated my dual identity as both student researcher and academic by reflecting on my positionality and the effect this has had on my research (see Chapter Three). My field research journal was a useful tool in this ongoing process of reflexivity. I consider that, overall, my positionality as an embedded participant positively contributed to the collection of primary data through an in-depth understanding of the goals and processes of Climate Camp Aotearoa.

As a candidate for a Master's degree in Environmental Studies from Victoria University of Wellington, I was unable to follow all seven guiding principles of scholar activism 
(Chatterton, Hodkinson and Pickerill, 2010) due to time constraints. However, this research has attempted to engage with radical discourses within academia, relying heavily on autonomous geography discourses, the work of activist scholars and acknowledging web-based activist publications where appropriate.

Most significantly, this research is strongly committed to an ethic of social transformation. As an activist scholar, I created a non-academic research output for the use of Climate Camp Aotearoa.

\section{Contribution to Climate Camp Aotearoa}

In undertaking research as an activist scholar, I am aware of an ethical obligation and desire to contribute positively to Climate Camp Aotearoa. An important driver in this research process has been an intention to benefit Climate Camp Aotearoa and thus enhance climate activism within Aotearoa. To this end, I have created a text for the use of Climate Camp Aotearoa: Climate Camp Aotearoa: an exploration. This text presents the results of my thesis in a non-academic, colloquial manner. The distribution of Climate Camp Aotearoa: an exploration took place in late May 2011 by means of both email and face-to-face contact.

The initial aim of distributing of this text was to encourage reflection in a time of relative inaction for Climate Camp Aotearoa. I have received six responses thus far, each indicating that the booklet has reminded activists of the reasons for their involvement and inspired them to become active in Climate Camp Aotearoa once more. Whether these responses will come to future fruition is unknown, but I consider this an extremely positive initial reaction and a possible indication of the commitment of this research to social transformation resulting in tangible effects.

The primary lesson that has been suggested by this research is that Climate Camp Aotearoa should organize more physical Climate Camps if the collective wishes to further politicize activists. 


\section{Future research}

This research joins both international texts on autonomous geographies and the limited research that exists on climate and environmental activism in Aotearoa. Overall, this thesis links to international research committed to radical social change by academics in a variety of fields.

Given the pressing nature of the climate crisis and the ever-changing nature of activist groups, there is a pressing need for more work to occur on climate activism in Aotearoa. Firstly, I suggest a greater academic concentration on documenting local activist groups and social movements. Secondly, I recommend that autonomous geography discourses are further applied to the study of autonomous activist groups in Aotearoa. To my knowledge there has been no prior academic work conducted using autonomous geography discourses in Aotearoa. There is vast scope for further study of autonomous political groups in Aotearoa and further application of autonomous geography discourses is needed to understand these specifically characterised groups. I recommend that research is carried out to:

- Deepen our understanding of the politicisation of activists in autonomous political groups in Aotearoa;

- Examine the effectiveness of direct democracy processes in Aotearoa;

- Explore the societal effects of the creation of alternative visions of the future in Aotearoa; and

- Examine relationships between national and international autonomous political groups.

I consider an understanding of autonomous geographies would benefit academic research in a broad variety of subject fields by encouraging an emphasis on diversity, autonomy and decentralisation. The discipline of Environmental Studies would be positively influenced by a greater theoretical understanding of how radical social change relates to climate change. As discussed in prior chapters, it is important that autonomous and activist practices are allowed to claim legitimate space in society, including areas of knowledge production. 
Overall, I recommend a scholar activist epistemological framework to activist researchers and encourage active acknowledgement of the:

"[...] false distinction between academia and wider society in terms of both sites of struggle and knowledge production" (Chatterton, Hodkinson and Pickerill, 2010:276).

I hope that activists increasingly undertake academic research concerning their activist groups, and that researchers become increasingly involved in the social movements and activist groups they study. In blurring this imagined boundary between academia and activism, radical change will become increasingly possible both inside and outside the academy. 


\section{Bibliography}

350 Aotearoa. (n.d.) About. Retrieved 17 March 2011, from: http://www.350.org.nz/about

Australian Associated Press (AAP) (2011, July 11). Keys defends NZ's ETS amid criticism. Yahoo News. Retrieved from: http://nz.news.yahoo.com/a/-/world/9820406/keys-defendsnzs-ets-amid-criticism/

Anderson, J. (2004). The ties that bind? Self- and place-identity in environmental direct action. Ethics, Place and Environment 7 (1-2), 45-57.

Askins, K. (2009). 'That's just what I do': Placing emotion in academic activism. Emotion, Space and Society 2, 4-13.

Baxter, J. K. (1971). Jerusalem daybook. Wellington: Price Milburn.

Belich, J. (2001). Paradise reforged: A history of New Zealanders from the 1980s to the year 2000. Auckland: Allen Lane.

Blee, K.M. \& Taylor, V. (2002). Semi-structured interviewing in social movement research. In B. Klandermans \& S. Staggenborg (Ed.s), Methods of social movement research. Minneapolis: University of Minnesota Press.

Boraman, T. (2007). Rabble rousers and merry pranksters: a history of anarchism in Aotearoa/New Zealand from the mid 1950s to the early 1980s. Christchurch: Katipo.

Brand, U., Bullard, N., Lander, E. \& Mueller, T. (2009). Radical climate change politics in Copenhagen and beyond: from criticism to action? In E. Lander, W. Bello, U. Brand, N. Bullard, \& T. Mueller (Ed.s), Contours of climate justice: ideas for shaping new climate and energy politics. Uppsala: Dag Hammerskjoeld Foundation.

Brendish, L. (2010, July 1). ETS opinion round-up. New Zealand Celcias. Retrieved from: http://www.celsias.co.nz/article/ets-opinion-round/

Brown G. \& Pickerill, J. (2009). Space for emotion in the spaces of activism. Emotion, Space and Society, 2, 24-35

Brunnengraeber, A. (2009). Kyoto's 'flexible mechanisms' and the right to pollute the air. In E. Lander, W. Bello, U. Brand, N. Bullard, \& T. Mueller (Ed.s) Contours of climate justice: ideas for shaping new climate and energy politics. Uppsala: Dag Hammerskjoeld Foundation.

Building Bridges Collective (2010). Space for movement. Leeds: Footprint Workers Co-op.

Camp for Climate Action Aotearoa (n.d). Camp for Climate Action Aotearoa. Retrieved 28 February 2011, from: www.climatecamp.org.nz/ 
Camp for Climate Action UK (n.d). About us. Retrieved 28 February 2011, from: www.climatecamp.org.uk/about

Castoriadis, C. (1991). Philosophy, politics, autonomy: essays in political philosophy. Oxford: Oxford University Press.

Chacko, E. (2004). Positionality and Praxis: fieldwork experiences in rural India. Singapore Journal of Tropical Geography. 25 (1), 51-63.

Chatterton, P. (2008). Using geography to teach freedom and defiance: lessons in social change from 'autonomous geographies'. Journal of Geography in Higher Education. 32 (3), 419440.

Chatterton, P., Hodkinson, S. \& Pickerill, J. (2010). Beyond scholar activism: making strategic interventions inside and outside the neoliberal university. ACME. 9 (2), 425-275.

Chatterton, P. \& Pickerell, J. (2010). Everyday activism and transitions towards post-capitalist worlds. Transactions of the Institute of British Geographers, 35, 475-490.

Chester, G. \& Walsh, I. (2008). Complexity and social movements: multitudes at the edge of chaos. London: Routledge.

Cleaver, H. (1979): Reading Capital politically. Brighton: Harvester.

Clements, K. (1988). Back from the brink. Wellington: Allen and Unwin.

Climate Justice Taranaki (2011). Media Release: TRC reveals toxic chemicals in Taranaki frack job. Retrieved $18^{\text {th }}$ July 2011, from:

http://climatejusticetaranaki.wordpress.com/2011/06/27/media-release-trc-reveals-toxicchemicals-in-taranaki-frack-job/

Coal Action Network Aotearoa. (2011). Keep the coal in the hole: why NZ's lignite should not be mined. Retrieved 18 July 2011, from:

http://coalactionnetworkaotearoa.wordpress.com/2011/07/02/keep-the-coal-in-the-holewhy-nzs-lignite-should-not-be-mined-jeanette-fitzsimons/

Collins, R. (1990). Stratification, emotional energy, and the transient emotions. In T. Kemper (Ed.) Research agendas in the sociology of emotions. Albany: State University of New York Press.

Cook 'et al.', I. (2005). Positionality / situated knowledge. In D. Atkinson, P. Jackson, D. Sibley $\&$ N. Washbourne (Ed.s) Cultural geography: a critical dictionary of key concepts. London: L.B.Tauris \& Co Ltd.

Crutzen, P.J and Stoermer, E.F. (2000). The Anthropocene. International Geosphere-Biosphere Programme Newsletter, 41. 
Dann, C. (1985). Up from under: women and liberation in New Zealand 1970-1985. Wellington: Allen and Unwin.

Dann, C. (2002). Losing ground? Environmental problems and prospects at the beginning of the twenty-first century. In E. Pawson \& T. Brooking (Ed.s) Environmental Histories of New Zealand. Melbourne: Oxford University Press.

Day, R. (2004). From hegemony to affinity. Cultural Studies. 18 (5), 716-748.

De Cleyre, V. (1912). Direct action Retrieved 17 March 2011, from: www.spunk.org/library/writers/decleyre/sp001334.html

Doherty, B, Plows, A. \& Wall, D. (1997). Environmental direct action in Manchester, Oxford and North Wales: a protest event analysis. Environmental Politics, 6 (5), 805-825.

Eden, M. (1999). Wild greens destroy GE experimental crops in NZ. Retrieved 5 October 2010, from: www.gene.ch/gentech/1999/Mar-Apr/msg00075.html

England, Kim. (1994). Getting personal: reflexivity, positionality, and feminist research. Professional Geographer 46, (1), 80-89.

Fallow, B. (2009, September 17). Carbon bill time bomb for taxpayer. New Zealand Herald. Retrieved from: www.nzherald.co.nz/greenpeace/news/article.cfm?o_id=320\&objectid=10597735

Farrow, H., Moss, P. \& Shaw, B. (1995). Concluding remarks. Antipode, 27, 100-101.

Flesher Fominaya, C. (2007). The role of humour in the process of collective identity formation in autonomous social movement groups in contemporary Madrid. International Review of Social History, Humour and Social Protest, 52, 243-258

Franks, B. (2003). Direct action ethic. Anarchist Studies, 11, 13-41.

Fyson, G. (1971). The new wave of protest: a socialist strategy for New Zealand. Wellington: Socialist Books.

Gibson-Graham, J. K. (1996). The end of capitalism (as we knew it): a feminist critique of political economy. Oxford: Blackwell Publishers.

Gibson-Graham, J. K. (2006). A postcapitalist politics. Minneapolis: University of Minnesota Press.

Gibson-Graham, J. K. (2008).Diverse economies: performative practices for 'other worlds'. Progress in Human Geography 32 (5), 613-632. 
Gilbert, Melissa (1994). The politics of location: doing feminist research at 'home'. Professional Geographer 46, (1), 90-96.

Global Justice Ecology Project (n.d.). What is climate justice? Retrieved on 20 February 2011, from: www.globaljusticeecology.org/climate_justice.php

Goldman, A. (2007). State repression in Aotearoa / New Zealand. Retrieved on 20 February 2011, from: www.earthfirstjournal.org/article.php?id=335

Greenpeace Aotearoa (n.d) Sign On. Retrieved on 28 July 2011, from: www.greenpeace.org/new-zealand/en/take-action/Take-action-online/Sign-On/

Greenpeace Aotearoa (2010). Media release: Greenpeace welcomes u-turn on mining as opportunity for Key to set new economic course. Retrieved on 20 February 2011, from: www.greenpeace.org/new-zealand/en/press/mining-u-turn-welcomed/

Gregory, D., Johnston, R., Pratt, G., Watts, M. \& Whatmore, S. (2009). The dictionary of human geography, fifth edition. Scotland: Wiley-Blackwell.

Grosz, E. (1999). Becomings: explorations in time, memory and futures. Ithaca: Cornell University Press.

Hamed, O. (2008). Direct action and environmental protest in Aotearoa, 1997-2009. Unpublished dissertation, The University of Auckland, Auckland.

Hardt, M. \& Negri, A. (2000). Empire. Cambridge: Harvard University Press.

Harvey, D. (2001). Spaces of Hope. Berkeley and Los Angeles: University of California Press.

Hetherington, K. (1998). Expressions of identity. London: SAGE.

Holloway, J. (2002): Change the world without taking power. London: Pluto.

Holmgren, D. (2007). Essence of permaculture: a summary of permaculture concepts and principles taken from 'permaculture principles \& pathways beyond sustainability. Retrieved on 4 July 2011, from: http://permacultureprinciples.com/freedownloads_essence.php

hooks, b. (1990). Yearning: race, gender, and cultural politics. Boston: South End Press.

hooks, b. (2004). Teaching community. a pedagogy of hope. London: Routledge.

Hoskins, C. (1991). In the interests of Maori women? Discourses of reclamation. Women's Studies Journal, 13 (92), 25-44. 
Hutchings, J. (2002). Te whakaruruhau, te ukaipo: Mana Wahine and genetic modification. Unpublished thesis, Victoria University of Wellington, Wellington.

Hutchinson, R.H. (1916). The "socialism" of New Zealand. New York: New Review.

Jackson, P. \& Penrose, J. (Ed.s) (1993). Constructions of race, place and nation. London: UCL Press.

James, J. (1999). The art of moral protest. Chicago: University of Chicago Press.

Johnston, R.J. \& Sidaway, J.D. (2004). Geography and geographers. London: Arnold.

Jordan, J. (1998). The art of necessity. In McKay. In G. McKay (Ed.) DiY culture. London: Verson.

Juris, J. S. (2008). Performing politics: image, embodiment, and affective solidarity during anticorporate globalisation protests. Ethnography, 9, 61-97.

Keenan, D. (2002). Bound to the land: Maori retention and assertion of land and identity. In E. Pawson, and T. Brooking (Ed.s) Environmental histories of New Zealand. Melbourne: Oxford University Press.

Kelsey, J. (1995). Economic fundamentalism. London: Pluto Press.

Kelsey, J. \& O'Brien, M. (1995). Setting the record straight: social development in Aotearoa/ New Zealand. Wellington: Association of Non Governmental Organizations.

King, M. (2003). History of New Zealand. Auckland: Penguin.

Kitchen, R. \& Hubbard, P. (1999). Research, action and 'critical' geographies. Area, 31 (4), 195198.

Klein, N. (2002). Fences and windows. London: Flamingo.

Klein, N. (2004). Reclaiming the commons. In T. Mertes (Ed.) A movement of movements: is another world really possible. London: Verso.

Lawrence, E. (2006). Border crossing and virtual voyaging: youth participation and the use of the internet to create change in Suva, Fiji. Unpublished thesis, Victoria University of Wellington, Wellington.

Locke, E. (1922). Peace people: a history of peace activists in New Zealand. Christchurch: Hazard Press.

McDowell, L. (1993) Space, place and gender relations. Progress in Human Geography 17(2), 157-179. 
McKnight, David. (2005) Beyond right and left: new politics and the culture wars. New South Wales: Allen \& Unwin.

MaCaskill, S. (1976). Sexism and egalitarian myth in New Zealand society. In P. Bunkle, S. Levine \& C. Wainwright (Ed.s) Learning about sexism in New Zealand. Wellington: Learnmonth.

Maddison, S. \& Scalmer, S. (2006). Activist wisdom: practical knowledge and creative tension in social movements. Sydney: University of New South Wales Press.

Mann, M. (1986): The sources of social power, vol. 1. Cambridge: Cambridge University Press.

Masters, C. \& Gower, P. (2007, October 20). Guerillas in the mist. New Zealand Herald. Retrieved from: www.nzherald.co.nz/nz/news/article.cfm?c_id=1\&objectid=10471026

Maxey, Ian. (1999). Beyond boundaries? Activism, academia, reflexivity and research. Area, 31 (3), 199-208.

Melucci, A. (1996). Challenging codes: collective action in the information age. Cambridge Cambridge University Press.

Melucci, A. (1989). Nomads of the present: social movements and individual needs in contemporary society. Philadelphia: Temple University Press.

Ministry for the Environment (2008). Management of genetic modification in New Zealand. Retrieved from: www.mfe.govt.nz/issues/organisms/conditionally-released/cabinetpaper-management-of-genetic-modification.html

Moorfield, J.C. (2005). Te whanake te aka: Maori-English, English-Maori dictionary and index. Auckland: Longman/Pearson Education NZ.

Morse, V. (2008). Land of the long white lie: the New Zealand terror raids. Retrieved from: http://october15thsolidarity.info/node/254

Moss, P. (2007). Feminisms in geography: rethinking space, place, and knowledge. Lanham: Rowman \& Littlefield Publishers.

Muller, T. \&Passadakis, A. (2009). Green capitalism and the climate: It's economic growth, stupid! In E. Lander, W. Bello, U. Brand, N. Bullard, \& T. Mueller (Ed.s), Contours of Climate Justice: ideas for shaping new climate and energy politics. Uppsala: Dag Hammerskjoeld Foundation.

Nagar, R. (2002). Footloose researchers, "travelling" theories, and the politics of transnational feminist praxis. Gender, Place and Culture, 9 (2), 179-86. 
Nast, H. (1994). Women in the field: critical feminist methodologies and theoretical perspectives. Professional Geographer, 46 (1), 54-66.

Newnham, T. (1986). Peace squadron: the sharp end of nuclear protest in New Zealand. Auckland: Graphic.

Notes From Below (2010). Interview with Tadzio Mueller - C.J.A. spokesperson. Retrieved from: http://notesfrombelow.wordpress.com/2010/01/18/interview-with-tadzio-muller-c-j-aspokesperson/

NZPA (1999, April 7) Salmon hatchery picketed. Nelson Mail. Retrieved from: www.highbeam.com/doc/1P2-18618900.html

NZPA (2010, May 1) Huge protest says no to mining on conservation land. New Zealand Herald. Retrieved from: www.nzherald.co.nz/greenpeace/news/article.cfm?o_id=320\&objectid=10642083

NZPA (2011, April 2) Hundreds welcome flotilla opposed to drilling. Tangata Whenua News. Retrieved from: http://news.tangatawhenua.com/archives/11096

Pain, R. \& Francis, P. (2003). Reflections on participatory research. Area, 35 (1), 46-54.

Pawson, E. \& Brooking. T. (2002). Environmental histories of New Zealand. Melbourne: Oxford University Press.

Peace Action Wellington (2005). Peace Movement Aotearoa. Retrieved from: www.converge.org.nz/pma/19mar05.htm

Peat, N. (1994). Manapouri saved! New Zealand's first great conservation success story. Dunedin: Longacre Press.

Pickerill, J \& Chatterton, P. (2006). Notes towards autonomous geographies. Creation, resistance and self management as survival tactics. Progress in Human Geography, 30 (6), 1-17.

Pihama, L. (2001). Tihei mauri ora, honouring our voices. Unpublished thesis, University of Auckland, Auckland.

Polletta, F. (2002). Freedom is an endless meeting. Chicago: University of Chicago Press.

Porter, D.P. \& Sidney. T. (2005). Transnational processes and social activism: an introduction. In D. P. Porter \& S. Tarrow (Ed.s), Transnational protest and global activism. Lanham: Rowman and Littlefield Publishers.

Pringle, R. (2002). Living the contradictions: a Foucauldian examination of my youthful rugby experiences. In H. Worth, A. Paris and L. Allen (Ed.s), The life of Brian: masculinities, sexualities and health in New Zealand. Dunedin: Otago University Press. 
Pulido, L. (2003). The interior life of politics. Ethics, Place and Environment. 6 (1), 46-52.

Quiggen, J. (2001). Social democracy and market reform in Australia and New Zealand. In A. Glynn (Ed.), Social democracy in neoliberal times: the left and economic policy since 1980. Oxford \& New York: Oxford University Press.

Rose, G. (1993). Feminism and geography: The limits of geographical knowledge. Minneapolis: University of Minnesota Press.

Rose, G. (1995). The interstitial perspective: a review essay on Homi Bhabha's 'The location of Culture'. Society and Space 13, 365-73.

Rose, G. (1997). Situating knowledges: positionalities, reflexivities and other tactics. Progress in Human Geography 21 (3), 305-320.

Roth, B. (1974). Trade unions in New Zealand. Wellington: Reed.

Routledge, P. (1996). The third space as critical engagement. Antipode, 28 (4), 399-419.

Routledge, Paul. (2003). River of resistance: critical collaboration and the dilemmas of power and ethics. Ethics, Place and Environment, 6, (1), 66-73.

Routledge, P., Cumbers, A. \& Nativel, C. (2007). Grassrooting network imaginaries: relationality, power, and mutual solidarity in Global Justice Networks. Environment and Planning A, 39 (11), 2575-2592.

Routledge, P. (2009). Activism. In D. Gregory, R. Johnston, G. Pratt, M. Watts \& S. Whatmore (Ed.s), The dictionary of human geography. Scotland: Wiley-Blackwell.

Rudningen, J. (2009). Transition Towns: an intervention method for encouraging proenvironmental behaviour change. Unpublished thesis, Victoria University of Wellington, Wellington.

Saunders, A. (1896). The history of New Zealand. Wellington: Whitcombe \& Tombs.

Save Happy Valley, (n.d). The history of the campaign. Retrieved on 5 May 2011, from: www.savehappyvalley.org.nz/getinvolved.php?page=ourhistory

Scott, D. (1954). The Parihaka story. Auckland: Southern Cross Books.

Sen, J. (2010). On open space: explorations towards a vocabulary of more open politics. Antipode, 42 (4), 994-1018.

Sharp, R. (1997). Justice and the Maori: The philosophy and practice of Maori claims in New Zealand since the 1970's (second edition). Auckland: Oxford. 
Sharples, P. (2006). Loss and grief-uncensored. Retrieved from: www.scoop.co.nz/stories/PA0610/S00280.htm

Sinclair, K. (1959). A history of New Zealand. Harmondsworth: Penguin Books Ltd.

Smith, L. (1992). Maori women: discourses, projects, and Mana Wahine. In S. Middleton \& A. Jones, A. (Ed.s), Women and education in Aotearoa 2. Wellington: Bridget Williams Books.

Smith, L. (1999). Decolonising methodologies. Zed Books, London.

Smith, P. (2009, May) Rudd delays carbon trading. The Financial Times. Retrieved from: http://www.ft.com/intl/cms/s/0/8fe917cc-390c-11de-8cfe00144feabdc0.html\#axzz1TSIIvtZd

Stern, N. (2007). The economics of climate change: the Stern review. United Kingdom: HM Treasury.

Stop the Search and Surveillance Bill (n.d.). Retrieved on 3 March, 2011, from: http://stopthebillnow.blogspot.com/

Soule, M. \& Press, D. (1998). What is Environmental Studies? BioScience, 48 (5), 397.

Swyngedouw, E. (2008). Where is the political? University of Manchester research document, retrieved from:

www.socialsciences.manchester.ac.uk/disciplines/politics/research/hmrg/activities/docum ents/Swyngedouw.pdf

Swyngedouw, E. (2009). The antinomies of the postpolitical city: in search of a democratic politics of environmental production. International Journal of Urban and Regional Research, 33 (3), 601-620.

Swyngedouw, E. (2010). Apocalypse forever? Post-political populism and the spectre of climate change. Theory Culture \& Society, 27 (2-3), 213-232.

Tarrow, S. (1998). Power in movement: social movements and contentious politics. Cambridge: Cambridge University Press.

Tarrow, S. (2005). The dualities of transnational contention: "two activist solitudes" or a new world altogether. Mobilisation: An International Journal, 10 (1), 53-72.

Taylor, R. (1974). Te Ika a Maui, or, New Zealand and its inhabitants. Wellington: A. H. \& A. W. Reed.

Thomas, D. (2008). What's Left? An exploration of social movements, the Left and activism in 
New Zealand Today. Unpublished thesis, Victoria University of Wellington, Wellington.

Tolich, M., \& Davidson, C. (1999). Starting fieldwork: an introduction to qualitative research in New Zealand. Auckland: Oxford University Press New Zealand.

TPP Action Group (2011). Press release: Wellington forum on the TPP shows public concern. Retrieved at: www.scoop.co.nz/stories/PO1107/S00080/wellington-forum-on-the-tppshows-public-concern.htm

Trotter, C. (2007). No left turn: the distortion of New Zealand's history by greed, bigotry and right-wing politics. Auckland: Random House.

Turner, T. V. (2007) Exploring the role of Mana Wahine in the development of Te Whare Rokiroki Maori Women's Refuge. Unpublished thesis, University of Victoria, Wellington.

United Nations Framework Convention on Climate Change (UNFCCC) (1994). Full text of the convention. Retrieved from:

http://unfccc.int/essential_background/convention/background/items/1349.php

Vaneigem, R. (1979): Revolution of everyday life. London: Rising Free Collective.

Vasil, R. (2000). Biculturalism: reconciling Aotearoa within New Zealand. Wellington: Institute of Policy Studies.

Walker, R. (1983). History of Maori activism. Auckland: NCC Program of Racism.

Walker, R. (1992). Sovereignty: Te Tino Rangatiratanga. In D. Novitz \& B. Willmott (Ed.s) New Zealand in crises: a debate about today's critical issues. Wellington: GP Publications.

Woodham, K. (2010, July 4). Smith's ETS backflip. New Zealand Herald. Retrieved from: www.nzherald.co.nz/opinion/news/article.cfm?c_id=466\&objectid=10656324

Yang, G. (2000). Achieving emotions in collective action. The Sociological Quarterly, 41 (4), 593-614.

Young, A. (2006, October 23). Turia's proposal shock to Maori. New Zealand Herald Retrieved from: www.nzherald.co.nz/nz/news/article.cfm?c_id=1\&objectid=10407146

Young, D. (2004). Our islands, our selves: a history of conservation in New Zealand. Dunedin: University of Otago Press.

Zizek, S. (2000). The ticklish subject - the absent centre of political ontology. London:Verso. 


\section{Semi-structured Interview Schedule}

\section{Master's Thesis Research Project:}

"Locating Camp for Climate Action Aotearoa:

An exploration of climate activism in New Zealand."

\section{Introductory Questions}

- Where you involved in activism before Camp for Climate Action Aotearoa?

- How long have you been involved in Camp for Climate Action Aotearoa?

- What does Camp for Climate Action Aotearoa mean to you?

- How have/do you participate in Camp for Climate Action Aotearoa?

- What/who influenced you to participate in Camp for Climate Action Aotearoa?

- What was it like getting involved? Was it difficult or easy?

- Do you still feel as motivated in participating as you did initially?

- What other environmental/social justice groups are you currently involved in?

- Why do you think people are motivated to participate in Camp for Climate Action Aotearoa?

\section{Generic Prompts examples:}

"Can you give me another example?"

"Really?"

"So how did that happen?"

"Why do you think that was?"

"Had this happened before?"

"Could you elaborate?"

"How?" 


\section{Master's Thesis Research Project:}

"“"Locating Camp for Climate Action Aotearoa:

An exploration of climate activism in New Zealand."

\section{INFORMED CONSENT FORM}

\section{Introduction}

The Victoria University of Wellington Human Ethics Committee, which has approved this research project, requires that all research involve participants are: 1) fully informed about the nature of the research; and 2) consent to participate. This "Informed Consent Form" has been designed in accordance with these requirements, to inform all participants about the nature of the project and their participation in it. It is meant to ensure that research participants and their communities are protected from any harm potentially arising from their participation in the research process.

\section{Purpose of the Study}

This study, for my master's thesis, is intended to answer the following question: What is the the 'nature' of Camp for Climate Action Aotearoa (CCAA), that is: the characteristics and qualities which define and politically locate CCAA and CCAA participants in Aotearoa New Zealand? Please also see the attached 'Information Sheet'

\section{Research Format}

Participants will be asked to take part in a semi-structured interview, at a time and a place that suits them. Participants are being asked to consent to data being confidentially collected from them on: why they chose to get involved in CCAA; what motivates them to continue participating; and what they consider CCAA brings to the climate movement in Aotearoa New Zealand. Interviews will be one-on-one and semi-structured. Each interview will last approximately thirty minutes and will not exceed one hour.

\section{Right of Withdrawal}

You have the right to withdraw yourself and any information you have provided from the research process. You may request that the transcript of your interview be destroyed and not used in the study, for any reason. You must inform me of your withdrawal no more than 8 weeks after the date of the interview, on 

Please circle one

1. I agree to an audio recorded interview with Liz Willoughby-Martin and I have been given and have understood an explanation of the research.

$$
\mathrm{Y} / \mathrm{N}
$$

2. My identity will remain confidential. I would like to be identified as (please circle one):

a) A letter code, or

b) Other, please specify:

3. I consent to information or opinions that I have given being attributed to this identification in any reports on this research.

$$
\mathrm{Y} / \mathrm{N}
$$

4. I understand that I will have an opportunity to correct the transcript of the interview before publication.

$$
\mathrm{Y} / \mathrm{N}
$$

5. I understand that the data I provide will not be used for any other purpose than described in the 'Information Sheet' or released to others without written consent.

$$
\mathrm{Y} / \mathrm{N}
$$

6. I would like to receive a summary of the results of this research when it is completed.

If yes, my address is:

$$
\mathrm{Y} / \mathrm{N}
$$

my email is:

I agree to take part in this research

Participant:

Name:

Date:

Signature:

Researcher:

I certify that this form and its attached "Information Sheet" cover letter provide a complete and accurate description of the aims and processes of this research project.

Name:

Date:

Signature: 


\title{
S59
}

\section{Participant Information Sheet}

\author{
Master's Thesis Research Project: \\ "Locating Camp for Climate Action Aotearoa: \\ An exploration of climate activism in New Zealand."
}

[November, 2010]

\begin{tabular}{|c|c|c|}
\hline $\begin{array}{l}\text { Researcher: } \\
\text { Telephone: } \\
\text { Mobile: } \\
\text { Supervisor: } \\
\text { Email: }\end{array}$ & $\begin{array}{l}\text { Elizabeth Willoughby-Martin } \\
\text { (04) } 3843839 \\
0211180335 \\
\text { Jessica Hutchings } \\
021406226 \\
\text { elizabethjane.wm@gmail.com }\end{array}$ & $\begin{array}{l}\text { School of Geography, Environment } \\
\text { and Earth Sciences (SGEES) } \\
\text { Victoria University of Wellington } \\
\text { PO BOX } 600 \\
\text { Wellington } 6140 \\
\text { (04) 463-5337 }\end{array}$ \\
\hline
\end{tabular}

Dear Project Participant,

You are being asked to take part in an interview for my Master's thesis at Victoria University of Wellington. The Victoria University of Wellington Human Ethics Committee, which has approved this research project, requires that all research involve participants who are: 1) fully informed about the nature of the research; and 2) consent to participate. This 'Participant Information Sheet' has been designed in accordance with these requirements, to inform all participants about the nature of the project and their participation in it. It is meant to ensure that research participants and their communities are protected from any harm potentially arising from their participation in the research process.

The project will investigate the characteristics and qualities which define and politically locate Camp for Climate Action Aotearoa (CCAA) and CCAA participants in Aotearoa New Zealand. The interviews will take place in a location agreed upon by both of us that is easily accessible for you. The key words for this research include: motivations, climate change, activism, and identity. The study will answer the following major question:

What is the 'nature' of Camp for Climate Action Aotearoa, that is: the characteristics and qualities which define and politically locate CCAA and CCAA participants in Aotearoa New Zealand?

The study will use a variety of research methods including literature reviews and semi-structured interviews.

I am inviting you to participate in a one-on-one semi-structured interview that will last approximately thirty minutes and will not exceed one hour.

\section{Confidentiality}

All data collected will be confidential. At the beginning of the interview, this will be repeated and I will explain in detail how the results of the research may be used, including the potential for publication in the public domain, in the form of academic papers in peer reviewed journals or presentations at conferences. The Informed Consent Form will ask you how you wish to identify yourself in the research. You will be referred to as a letter code or in any other way you request (see \#3. on the Informed Consent Form). 
No names will appear on the transcripts. A letter-number code will be assigned to each interview respondent, and only this code, or other title specified by you, will appear in the published results.

The real names associated with the codes will be kept securely by me, and never made public without the permission of the individual(s) involved.

\section{Storage and Disposal of Data}

Access to the written and electronic material will be restricted to me and my supervisor. All written material will be kept in a locked file, and all electronic material will be password protected. At the conclusion of the research, any interview material or similar will be destroyed and the audio recordings of the interviews will be electronically wiped.

The results collected will be reported in my thesis, and will be potentially presented in academic journals and conferences. The thesis will be submitted for marking to the School of Geography, Environment and Earth Sciences, Victoria University of Wellington.

\section{Right of Withdrawal}

During the course of the interviews, you will have the right to withdraw from the interview or refuse to answer any question(s) at any time. You may request that the transcript of your interview be destroyed and not used in the study, for any reason. You must inform me of your withdrawal no more than 8 weeks after the date of the interview.

\section{Provision of Feedback}

You have the right to check the interview transcript, and will be able to provide any corrections at any time, prior to final analysis of data.

\section{Community Access to Research Results}

In order to ensure that the results of this research project are accessible to the participants, a summary of the completed research output will be available. You may request it by circling 'Yes' in Question 7 of the 'Informed Consent Form' (attached), or on later request (by email to elizabethjane.wm@gmail.com). Furthermore, copies of the completed research output will be available from the School of Geography, Environment and Earth Sciences Library, and in the Victoria University of Wellington electronic database of theses.

If you have any other questions about this project, please feel free to ask me now, or contact me or my supervisor later, from the contact details provided on the first page of this sheet.

Thank you for participating!

Sincerely,

Liz Willoughby-Martin 